\title{
Article \\ A Combined Interval Type-2 Fuzzy MCDM Framework for the Resilient Supplier Selection Problem
}

\author{
Seyed Amirali Hoseini ${ }^{1}{ }^{(0}$, Sarfaraz Hashemkhani Zolfani ${ }^{2, *}$, , Paulius Skačkauskas ${ }^{3}$, Alireza Fallahpour ${ }^{4}$ \\ and Sara Saberi ${ }^{5}$ \\ 1 Department of Industrial Engineering, Iran University of Science and Technology, Tehran 13114-16846, Iran; \\ amirali.hoseiny1989@gmail.com \\ 2 School of Engineering, Catholic University of the North, Larrondo 1281, Coquimbo 1240000, Chile \\ 3 Department of Mobile Machinery and Railway Transport, Faculty of Transport Engineering, \\ Vilnius Gediminas Technical University, 10105 Vilnius, Lithuania; paulius.skackauskas@vilniustech.lt \\ 4 School of Mechanical Engineering, Universiti Teknologi Malaysia, Skudai 81310, Malaysia; \\ fallahpour.a@utm.my \\ 5 Robert A. Foisie School of Business, Worcester Polytechnic Institute, Worcester, MA 01609-2280, USA; \\ ssaberi@wpi.edu \\ * Correspondence: sarfaraz.hashemkhani@ucn.cl
}

Citation: Hoseini, S.A.;

Hashemkhani Zolfani, S.;

Skačkauskas, P.; Fallahpour, A.; Saberi, S. A Combined Interval Type-2 Fuzzy MCDM Framework for the Resilient Supplier Selection Problem. Mathematics 2022, 10, 44. https://doi.org/10.3390/ math10010044

Academic Editors: James Liou and Artūras Kaklauskas

Received: 2 December 2021

Accepted: 20 December 2021

Published: 23 December 2021

Publisher's Note: MDPI stays neutral with regard to jurisdictional claims in published maps and institutional affiliations.

Copyright: (C) 2021 by the authors. Licensee MDPI, Basel, Switzerland. This article is an open access article distributed under the terms and conditions of the Creative Commons Attribution (CC BY) license (https:// creativecommons.org/licenses/by/ $4.0 /)$.

\begin{abstract}
Selecting the most resilient supplier is a crucial problem for organizations and managers in the supply chain. However, due to the inherited high degree of uncertainty in real-life projects, developing a decision-making framework in a crisp or fuzzy environment may not present accurate or reliable results for the managers. For this reason, it is better to evaluate the potential suppliers in an Interval Type-2 Fuzzy (IT2F) environment for better dealing with this ambiguity. This study developed an improved combined IT2F Best Worst Method (BWM) and IT2F technique for Order Preference by Similarity to Ideal Solution (TOPSIS) model "Atieh Sazan" Co. as a case study, such that the IT2FBWM was employed for obtaining the weight of criteria. The IT2FTOPSIS was utilized for ranking the potential suppliers based on Hamming distance measure. In both phases, the opinions of experts as IT2F linguistic terms were employed for weighting the criteria and obtaining the relative importance of the alternatives in terms of the evaluative criteria. After obtaining the final results, the proposed model was validated by replacing Analytical Hierarchy Process (AHP) and Simple Additive Weighting (SAW) approaches separately instead of BWM for weighting the criteria. After executing both new models, it was found that the final ranking was similar to the final ranking of the proposed model, representing the reliability and accuracy of the obtained results. Moreover, it was concluded that the resilient criteria of "Reorganization" and "Redundancy" are the most determinant measures for selecting the best supplier rather than measures in the Iranian Construction Industry.
\end{abstract}

Keywords: resilient supplier selection; interval type-2 fuzzy set; multiple criteria decision making (MCDM); BWM; TOPSIS

\section{Introduction}

Supply chain management (SCM) is one of the most attractive issues among the related experts, according to its role in promoting the efficiency and income of different organizations [1,2]. The supplier selection problem is one of the most crucial subjects $[3,4]$ in SCM such that the disruption for finding the best supplier of raw materials had a huge negative effect on the income of nine different firms from China, Pakistan, Sri Lanka, and India during the COVID-19 pandemic [5]. Selecting the most appropriate one helps the organizations provide the products in the pre-determined value with a reasonable price promptly [6]. Globalization of the activities in different fields has transformed sourcing and supplier selection processes into a comprehensive process that can affect political, legal, and cultural issues [7]. Generally, because the supplier selection is effective on the 
whole supply chain, resiliency in this process should always be considered to decrease the vulnerability in the supply chain [8].

Generally, resilience is the system's ability to return to its primary state or a better one after emerging disruptions [9]. In this regard, different types of disruptions can emerge in sustainable supply chains because of many reasons in economic, social, and cultural aspects, and so on. These disruptions can negatively affect vital factors, including revenue, efficiency, quality, and competitiveness [10]. In other words, resilience is a type of management for identifying the potential disruptions, promoting the ability to control these identified disruptions and return back to the initial conditions [11]. Meanwhile, designing a resilient supply chain can keep industries away from disruptions [12].

Furthermore, a resilient supplier selection framework through Fuzzy Ordinal Priority Approach was successfully developed to help procurement managers in a kitchen utensil manufacturing company in Jiangsu, China, during the COVID-19 pandemic [13]. In this regard, an appropriate set of criteria must be formulated because selecting the best criteria is the essential part of the evaluation process $[14,15]$. It should be noted that the criteria should be localized according to the case study $[16,17]$.

In the field of supplier selection, many uncertainty aspects go along with the formal criteria, goal, system behavior, and, most crucially, with the decision makers' preferences [18]. Since the decision makers' preferences are described as subjective linguistic terms, crisp numerical values do not produce precise results. Therefore, fuzzy set theory has been paid attention to deal with the linguistic uncertainties. However, type- 1 fuzzy sets are not suitable to model words [19]. Since words mean different things to different people, they are uncertain. There are two types of linguistic uncertainties: intro-uncertainty, which refers to the uncertainty a person has about the word, and inter-uncertainty, which is the uncertainty related to a group of people [20]. Generally, type-1 fuzzy sets have some imperfections, including improper interpreting of word usage and sometimes the existence of noisy data from the group of experts [21]. Thus, Zadeh [22] proposed type-2 fuzzy sets to resolve these problems. Type-2 fuzzy sets are defined by two membership functions: primary membership function (PMF) and secondary membership function (SMF). Interval type-2 fuzzy sets (IT2FSs) are the most widely used in type-2 fuzzy sets since their computational complexity is lower than the general type-2 fuzzy sets (GT2FSs). Therefore, they are more applicable in real-life management problems [23]. In type-2 fuzzy sets, a word can be modeled using interval type-2 fuzzy sets handling linguistic uncertainties efficiently. In comparison, type-1 fuzzy sets have a two-dimensional membership function, while type-2 fuzzy set membership function is three-dimensional. The third dimension represents additional degrees of freedom for possibility in models, including uncertainty [21]. Of course, it should be noted that recently a new fuzzy set was presented, titled $(3,2)$-Fuzzy Sets, which may be suitable for dealing with more complex problems [24].

Generally, there are two main phases in suppliers' selection: (1) specifying the importance degree of the evaluative criteria and (2) assessing the suppliers' performance and ranking the alternatives. Several techniques have been employed about the first phase, e.g., AHP, ANP, and SAW. For the second phase, other approaches have been employed, including VlseKriterijumska Optimizcija I Kaompromisno Resenje (VIKOR), TOPSIS, and Fuzzy Inference System (FIS) [7].

The MCDM techniques used for the first phase of suppliers' selection have complex calculations that decrease their practical application, specifically when adding/removing several supplier alternatives is required [25]. To address this problem, one of the useful MCDM approaches is the Best-Worst Method (BWM), which was first developed by Rezaei [26]. The benefit of this approach is obtaining the relative weights of evaluative criteria by fewer calculations and paired comparisons associated with a lower level of inconsistency [27]. This method achieves higher accuracy than the traditional methods because it needs only the preference of the best criterion over other criteria and the preference of other criteria over the worst one [28,29]. For the second phase of supplier selection, the TOPSIS technique is a common method researchers have employed for ranking the 
alternatives [19,30-32]. The TOPSIS technique is more flexible than other MCDM ranking techniques and can reduce the inherent uncertainty and extra calculations in a complex case study, thereby simply obtaining the final result [33]. Another benefit of this method is its consistency with the IT2F environment, which can not be found in other MCDM ranking techniques such as VIKOR or even other decision-making approaches. Therefore, a reliable IT2F decision-making method can be developed based on the TOPSIS technique.

According to the points mentioned above, the main motivation for conducting this study is integrating resilience in the supplier selection process in a case study of an Iranian construction company ("Atieh Sazan" Co. is a major construction company in Iran) through a more applicable, improved model (which can be extended for other similar case studies) in an IT2F environment. Therefore, in this paper, an interval type-2 fuzzy improved TOPSIS model is developed. In this model, a new ranking index was developed according to the interval-valued fuzzy Hamming distance measure for prioritizing potential alternatives in the ranking process, which is consistent with the TOSPSIS method. The benefits of this method are as follows. (1) In comparison with the previous studies where the weight importance of decision makers has not been paid attention so much [34-37], this study applied the weight of each decision maker according to the improved interval type-2 fuzzy TOPSIS method in a more accurate manner in order to reduce/prevent the judgments' errors and increase the accuracy of the final results. (2) This paper develops an improved index for ranking the most resilient supplier. This model can reduce the inherent computational complexity of the IT2F environment since the resilient evaluative criteria are localized and defined according to our case study, the Iranian construction industry. These criteria are often qualitative, and a unique criterion may have different definitions and concepts in various case studies.

Generally, this study contributes to the following:

- Developing an improved decision-making system to assess suppliers' performance in the Iranian construction industry according to resilient criteria, in which BWM computes weights of the criteria. The performance of each supplier is assessed by an improved FTOPSIS in the IT2F environment, which has not been paid attention to in the previous studies.

- Developing an improved model for reducing the inherent computational complexity of the IT2F environment by utilizing two applicable techniques, in which the results can also be more accurate.

- Presenting a new set of resilient criteria for evaluating the performance of suppliers in the interval type-2 fuzzy environment for the Iranian construction industry, which has been neglected in the previous studies.

- Introducing the most determinant factors for selecting the most resilient supplier for the first time in the Iranian construction industry, which is more effective in this process, is helpful for the managers in this field.

- The results of this study can be extended to the construction industries in some countries with similar structures and economic conditions. These results can also be significant to similar industries in Iran, e.g., Home Appliance Manufacturing Industries.

\section{Literature Review}

Resilient supplier selection (RSS) is a relatively new concept in suppliers' performance evaluation and selection, and there are relatively fewer studies on RSS in comparison with Sustainable Supplier Selection (SSS) and Green Supplier Selection (GSS) [38,39]. The criteria of SSS are divided into three aspects of economic, social, and environmental dimensions, and most studies have concluded that the economic aspect is the most important one in the SSS [40-42]. However, in the GSS, the environmental dimension is crucially more important than other aspects [43]. In the RSS, the focus is on the resiliency and flexibility of suppliers [44]. The criteria of the RSS can be divided into four categories of benefits, opportunities, costs, and risks [6]. Of course, few studies investigate a combination of sustainable-resilient supplier selection $[10,16]$, green-resilient supplier selection $[17,45]$, 
or green-sustainable supplier selection [46,47]. Hence, the RSS has not been investigated thoroughly. In addition, the RSS criteria have not been specified and defined exactly in the previous studies since the RSS criteria are potentially qualitative. Therefore, this study sought to quantify and define these criteria precisely through the opinions of experts in the IT2F environment for our case study.

Here, we point out the recent studies in the field of RSS. Wang et al. [48] developed a hybrid approach including the analytic hierarchy process and Grey Relational Analysis (GRA) for resilient supplier selection in the construction industry, in which AHP was employed to weight the criteria and the GRA was employed for ranking the suppliers. They formulated 17 resilience criteria, which will be investigated in the following. Alimohammadlou and Bonyani [49] used techniques including (ANP), Decision making trial and evaluation laboratory (DEMATEL), and Goal Programming for resilient supplier selection in a fuzzy environment for Iran electronic industries. The results showed that human resource management, visibility, and financial strength are considered the most influential RSS factors. Davoudabadi et al. [34] developed a novel, integrated weighting and ranking model based on entropy, Data Envelopment Analysis (DEA), and Principal Components Analysis (PCA) for resilient supplier selection. They used PCA to decrease the dimensions and the correlation between the criteria and DEA to specify the criteria's weights and rank of suppliers. Additionally, in the Wood and Paper Industry, ValipourParkouhi and SafaeiGhadikolaei [6] integrated Fuzzy Analytic Network Process (FANP) and grey VIKOR techniques for resilient supplier selection. In their study, the importance level of the effective elements in the process was determined by the FANP, and the VIKOR specified the resiliency level of the suppliers. They concluded that variation in price, vulnerability, supplier's capacity limit, supplier's capability limit, visibility, supplier raw material acquisition difficulties, and on-time delivery are considered essential criteria in resilient supplier selection in this industry. These studies did not use IT2F analysis for supplier selection, whose results are more accurate and reliable.

Looking more closely into the employed methodologies for the RSS, Sureeyatanapas et al. [35] developed an Integration of Evidence Theory and Rule-Based Transformation into the TOPSIS for resilient supplier selection in a company producing computer hardware components. They employed Evidence Theory to handle the existence of uncertain and incomplete data. Moreover, they employed a rule-based transformation technique to convert various forms of the assessment results into a unified form. Pramanik et al. [50] developed a fuzzy-multicriterion quantitative approach for resilient supplier selection under a fuzzy environment. AHP and Quality Function Deployment (QFD) methods were used for weighting the criteria since resiliency criteria are mostly according to the subjective judgment of technical requirements and customer requirements. Moreover, the TOPSIS technique was employed to identify the features of general selection criteria and finally rank the alternatives. Their model was able to handle the conflicts among different decision makers, which is common in these problems.

Moreover, Mansory et al. [36] employed the TOPSIS technique for selecting the most resilient supplier in Fanavaran Petrochemical Company. In this study, they employed SWARA (StepWise Weight Assessment Ratio Analysis) decision-making technique and also the opinions of 30 experts for developing the resiliency and their weights. Besides, the efficiency of the obtained criteria was validated by path analysis. Moreover, Xiong et al. [37] integrated BWM, TOPSIS, and WASPAS (Weighted Aggregated Sum-Product Assessment) techniques for selecting a resilientgreen supplier. Apart from the BWM method for weighting the criteria, the WASPAS technique is integrated with the TOPSIS for more accurate results for ranking the alternatives. Furthermore, Gan et al. [51] employed FBWM to weigh the criteria and developed modular TOPSIS in random environments for group decision making to evaluate the suppliers. Since there is a lack of a united measuring index system for evaluating the resilient supplier, the evaluation language sets are typically crisp values. Wu et al. [52] used the BWM method in Interval type-2 fuzzy environment for resilient-green supplier selection. They also developed an extended VIKOR for ranking the alternatives, which is a suitable technique for reducing the vagueness and uncertainty in an 
interval type-2 fuzzy environment. Moreover, Celik and Gul [53] integrated BWM and MARCOS (The Measurement of Alternatives and Ranking according to Compromise Solution) methods under interval type-2 fuzzy sets' environment for hazard identification and risk assessment, in which two major parameters of the risk score were weighted by BWM and the priority orders of hazards were investigated by the MARCOS approach. Finally, Tang et al. [54] developed a combined TODIM (an acronym in Portuguese of interactive and multi-criteria decision making) and BWM model for Fine-Kinney under interval type-2 fuzzy environment for hybrid risk prioritization, almost the same as the previous paper. As it can be seen, no study developed a combined BWM-TOPSIS approach for resilient supplier selection. This study sought to develop an IT2F improved combined approach based on interval-valued fuzzy Hamming distance, which can simplify the calculations and obtain more accurate results. It can be employed for real case studies because the model considers all the uncertainties and vaguenesses in the process of supplier selection, so that the model is more practical.

After reviewing the related models in the current field, we discuss the different resilient criteria in previous studies, which are important in the evaluation process. Resiliency has the same concept for various case studies, with selection criteria in common and a similar concept but with localized features according to the case study. After reviewing many recent studies in RSS, we selected the studies in the table below with a comprehensive list of the resilient criteria that were consistent with the case study in this paper.

It should be noted that, in the next step, these criteria (Table 1) will be evaluated by the experts through a Likert scale (1-9) according to the case study and its features, and the criteria, which gain the minimum average of 6.5 , will be finally selected for the model in this study.

Table 1. Primary resilient criteria in the previous studies.

\begin{tabular}{|c|c|c|}
\hline Authors (Case Study) & Criteria & Extra Definition \\
\hline \multirow{10}{*}{$\begin{array}{l}\text { Waleekhajornlert and } \\
\text { Sureeyatanapas (Electronic } \\
\text { Industry) [55] }\end{array}$} & Responsiveness & The ability to quickly react or respond to customer requirements \\
\hline & Safety stock inventory & $\begin{array}{l}\text { The supplier's capacity to hold adequate values of essential materials } \\
\text { and goods to support customers during disruptive events [35]. }\end{array}$ \\
\hline & Invulnerable location & $\begin{array}{l}\text { The location of the supplier, that is not involved in the hazard of } \\
\text { natural disasters for minimizing effects on the procedures of the } \\
\text { supply chain, or be in an area with low possible hazards. }\end{array}$ \\
\hline & Backup supplier contracts & $\begin{array}{l}\text { The existence of contracts for supplier's outsourcing, enabling a } \\
\text { customer to handle the lack of supply capacity in the disruption time. }\end{array}$ \\
\hline & Robustness & $\begin{array}{l}\text { The infrastructure of physical preservation and existence of a safe } \\
\text { system of a building and facilities of the supplier, for minimizing } \\
\text { negative effects of disruption, specifically facing natural disasters. }\end{array}$ \\
\hline & Delivery rerouting & $\begin{array}{c}\text { Alternatives for rerouting (On the basis of supplier's location) or the } \\
\text { capability of the supplier in order to adjust transportation routes as } \\
\text { occurring disruptive events. }\end{array}$ \\
\hline & Restoration & $\begin{array}{c}\text { The capability of the supplier in order to restore ruined facilities and } \\
\text { equipment or to improve production to a normal state } \\
\text { during operations. }\end{array}$ \\
\hline & $\begin{array}{l}\text { Risk of production } \\
\text { interruption }\end{array}$ & $\begin{array}{c}\text { The possibility of a production interruption, which may be due to the } \\
\text { breakdown of the facilities, and machines, human errors, natural } \\
\text { disasters, and technological challenges. }\end{array}$ \\
\hline & $\begin{array}{l}\text { Risk of transportation } \\
\text { breakdown }\end{array}$ & $\begin{array}{l}\text { The possibility of transportation disruption, which may be due to } \\
\text { vehicle failure, insecurity of routes, possible attacks of terrorists, and } \\
\text { also natural disasters. }\end{array}$ \\
\hline & $\begin{array}{l}\text { Risk of transactions } \\
\text { breakdown and losing } \\
\text { information }\end{array}$ & $\begin{array}{l}\text { The possibility of the failure in communication and transactions, } \\
\text { which may be due to system errors and inconsistency, in addition to } \\
\text { the unsafety of the information system. }\end{array}$ \\
\hline
\end{tabular}


Table 1. Cont.

\begin{tabular}{|c|c|c|}
\hline Authors (Case Study) & Criteria & Extra Definition \\
\hline \multirow{8}{*}{$\begin{array}{l}\text { Fallahpour et al. } \\
\text { (Malaysian Palm oil } \\
\text { industry) [10] }\end{array}$} & Robustness & \\
\hline & Responsiveness & \\
\hline & Cooperation & $\begin{array}{l}\text { The ability of the supplier to cooperate with other suppliers and } \\
\text { customers for promoting the quality of materials. }\end{array}$ \\
\hline & Agility & The ability of the supplier for producing a product quickly. \\
\hline & Visibility & $\begin{array}{l}\text { The ability to share the related data, helping the customers in using } \\
\text { the product. }\end{array}$ \\
\hline & Risk reduction & $\begin{array}{l}\text { The ability of the supplier to forecast the different conditions and } \\
\text { decrease the risk in difficult situations. }\end{array}$ \\
\hline & Surplus inventory & Additionally available inventory for crucial or emergency conditions. \\
\hline & Restorative capacity & \\
\hline \multirow{4}{*}{$\begin{array}{l}\text { Xiong et al. } \\
\text { (Hypothetical) [37] }\end{array}$} & Surplus inventory & \\
\hline & Factory segregation & $\begin{array}{l}\text { It means that enterprises have scattered and spare sections, and each } \\
\text { section has similar technical situations and material deposits in order } \\
\text { to quickly be ready for production activities. }\end{array}$ \\
\hline & Reliability & $\begin{array}{l}\text { Establishing suitable cooperative relationships with partners } \\
\text { accompanied by recognition; in which enterprises can supply } \\
\text { materials and services at the right time, and accounts are obvious } \\
\text { with no mistake, and disruption cost is predetermined. }\end{array}$ \\
\hline & Reorganization & $\begin{array}{l}\text { The ability for integrating resources quickly and reconstructing } \\
\text { corporate culture and organization }\end{array}$ \\
\hline \multirow{8}{*}{$\begin{array}{l}\text { Wang et al. (Construction } \\
\text { Project) [48] }\end{array}$} & Delivery and service & $\begin{array}{l}\text { Delivery at the predetermined date (\%), due to the waiting time, and } \\
\text { also service efficiency. }\end{array}$ \\
\hline & Flexibility & Including time, product, and quantity flexibilities. \\
\hline & Management level & $\begin{array}{l}\text { Management techniques, management philosophy, philosophy of } \\
\text { operations, organization, and improved level of the } \\
\text { management process. }\end{array}$ \\
\hline & Reputation and prestige & $\begin{array}{l}\text { The supplier performance in its past competitive nature, production } \\
\text { results, and reaction to the market, etc. }\end{array}$ \\
\hline & $\begin{array}{l}\text { Political and legal } \\
\text { environment }\end{array}$ & Compliance with local law. \\
\hline & The informatization level & $\begin{array}{l}\text { The rate of information equipment assembly, and comprehensive } \\
\text { employment of data equipment }\end{array}$ \\
\hline & R\&D development & $\begin{array}{l}\text { Research and development capability for integrating innovations in } \\
\text { technology and adapting to market alterations }\end{array}$ \\
\hline & Eco-design & $\begin{array}{l}\text { Suitable Deign for resource efficiency, reuse of products, materials } \\
\text { recovery, reducing or eliminating hazardous materials, and } \\
\text { minimizing embodied energy }\end{array}$ \\
\hline
\end{tabular}


Table 1. Cont.

\begin{tabular}{|c|c|c|}
\hline Authors (Case Study) & Criteria & Extra Definition \\
\hline \multirow{10}{*}{$\begin{array}{l}\text { Alimohammadlou } \\
\text { and Bonyani } \\
\text { (Hypothetical) [49] }\end{array}$} & Velocity & $\begin{array}{l}\text { The rate of flexibility in operations, and also determining the } \\
\text { recovery rate of the supply chain following the disruption }\end{array}$ \\
\hline & Risk management culture & $\begin{array}{c}\text { Ensuring that all organizational members confirm supply chain risk } \\
\text { management, including top management support and } \\
\text { integration/teamwork. }\end{array}$ \\
\hline & Safety & $\begin{array}{l}\text { Providing a secure working environment for the employees to avoid } \\
\text { sudden accidents and injury during the work or even the } \\
\text { supplier operations [6] }\end{array}$ \\
\hline & Risk and revenue sharing & \\
\hline & Financial strength & \\
\hline & Redundancy & $\begin{array}{l}\text { The strategic and optional usage of extra material and service for } \\
\text { handling turbulence, for instance, spare facilities, and the existence of } \\
\text { many suppliers. }\end{array}$ \\
\hline & Complexity & $\begin{array}{l}\text { The function of the total nodes as well as forward, backward, or } \\
\text { within-tier streams in the supply chain. }\end{array}$ \\
\hline & Contingency planning & $\begin{array}{l}\text { Predicting potential happenings and determining the metrics for } \\
\text { dealing with the hazards and disruptions of the supply chain before } \\
\text { the occurrence, for instance by predicting and screening early } \\
\text { warning alarms. }\end{array}$ \\
\hline & Demand management & $\begin{array}{l}\text { Reducing the effects of disruptions by affecting customer options by } \\
\text { dynamic pricing, comprehensive planning, and silent } \\
\text { product changes. }\end{array}$ \\
\hline & $\begin{array}{l}\text { Human resource } \\
\text { management }\end{array}$ & $\begin{array}{l}\text { Training the staff for handling dangerous events and creating the } \\
\text { multi-task groups. }\end{array}$ \\
\hline
\end{tabular}

\section{Methodology}

Here, we graphically represent the overview of the whole methodology before describing it in detail, as shown in Figure 1:

\section{First phase:IT2FBWM}

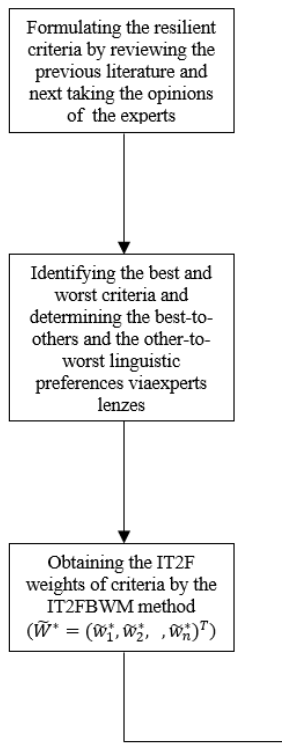

Second phase:IT2FTOSIS

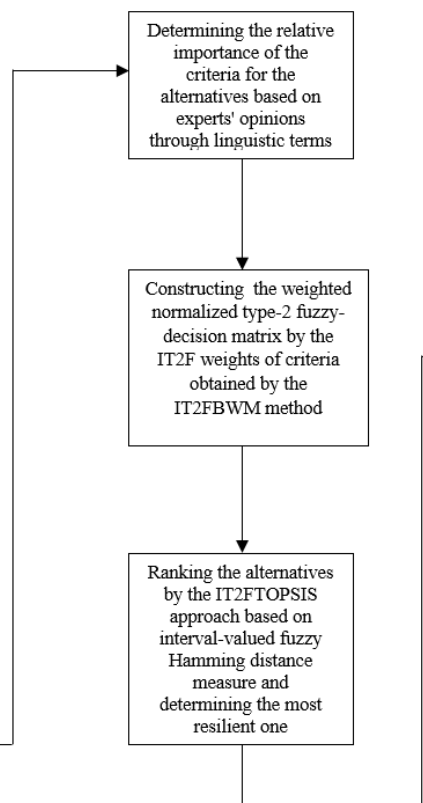

Validation phase

Figure 1. The structure of the proposed model for selecting the most resilient supplier. 


\subsection{First Phase: Interval Type-2 Fuzzy Best-Worst Method (IT2FBWM)}

In order to obtain criteria weights, preference relation (PR) should be constructed, which is shown as $a_{i j}$ for $\mathrm{n}$ criteria, where $a_{i j}$ shows the preference degree of the criterion " $i$ " over criterion " $j$ ". In this regard, if $a_{i j}=a_{i j} \times a_{k j}(\forall i, j, k \in \mathrm{N})$ is observed, the PR is completely consistent. However, because of expressing the preference degree, inconsistencies can often be observed. Identifying the most important and least important criterion in these problems is almost accessible and achievable [26]. As identifying the best and worst criteria, the linguistic preferences can be shown in two methods [52]:

- Best-worst linguistic reference vectors (BWLRVs);

- Secondary linguistic preference (SLP) elements.

Definition 1. $\left(a_{i 1}, a_{i 2}, \ldots, a_{i n}\right)$ and $\left(a_{1 j}, a_{2 j}, \ldots, a_{n j}\right)$ are shown as BWLRVs, so that " $i$ " and " $j$ " are the best and worst criteria, respectively.

Definition 2. If neither " $i$ " nor " $j$ " is the best or worst criteria, a linguistic preference $a_{i j}$ is defined as an SLP.

For an existing PR with $\mathrm{n}$ alternatives, the total number of comparisons would be $n^{2}$. By ignoring the diagonal elements, $n(n-1)$ comparisons remain. Regarding the interchange of a PR, at least $n(n-1) / 2$ comparisons are required. For the BWM approach, only $2 n-$ 3 comparisons are required, and the remaining are SLPs, as shown in Figure 2.

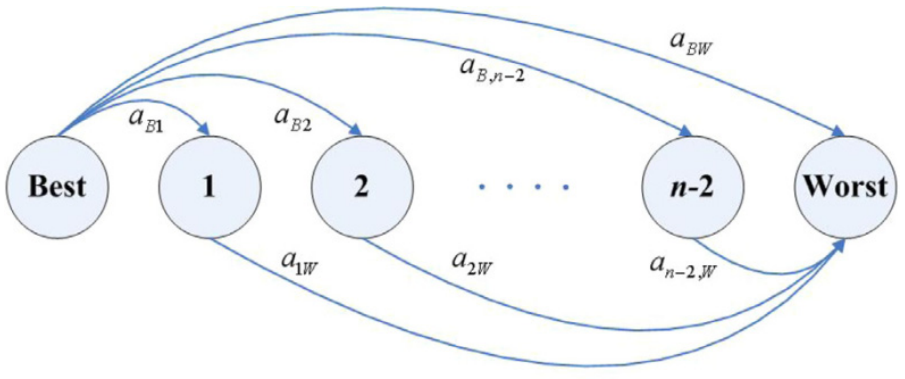

Figure 2. Reference comparisons.

In fact, the SLPs can be obtained using the BWLRVs. Each SLP $a_{i j}$ can be shown in two relation chains, including $a_{B e s t, i} \times a_{i j}=a_{B e s t, j}$ and $a_{i j} \times a_{j, \text { Worst }}=a_{i, \text { Worst }}$. In fact, the SLPs mediate in the comparison chain. Next, we would like to show how to derive the weights based only on the BWLRVs. BWLRVs can finally lead the criteria weights.

After performing BWLRVs, they can be transformed into IT2FSs based on Figure 2 and Table 2. The IT2F best-to-others (IT2FBO) and IT2F others-to-worst (IT2FOW) vectors are obtained as follows $\widetilde{A}_{B j}=\left(\widetilde{A}_{B 1}, \widetilde{A}_{B 2}, \ldots, \widetilde{A}_{B n}\right)$ and $\widetilde{A}_{j W}=\left(\widetilde{A}_{1 w}, \widetilde{A}_{2 w}, \ldots, \widetilde{A}_{n w}\right)$. The possible values of the $\widetilde{A}_{B}$ and $\widetilde{A}_{W}$ are graphically shown in Figure 3 and are numerically shown in Table 2.

According to Figure 3, the normal IT2FSs' word can be defined quantitatively as below. These words include Weak Importance (WI), Moderate Importance (MI), Moderate plus Importance (MpI), Strong Importance (SI), Strong plus Importance (SpI), very Strong Importance (vSI), very Strong Importance (vvSI), and Extreme Importance (EI).

Of course, it is obvious that $\widetilde{A}_{B B}=\widetilde{A}_{W W}=[(1,1,1,1),(1,1,1)]$.

Then, consistent IT2F preference (IT2FP) can be defined as below:

Definition 3. An interval type-2 fuzzy preference $\widetilde{A}_{j k}$ is consistent, if

$$
\widetilde{A}_{\text {Best.j }} \times \widetilde{A}_{j k}=\widetilde{A}_{\text {Best.k }}, \widetilde{A}_{j k} \times \widetilde{A}_{j, \text { Worst }}=\widetilde{A}_{j W}(\forall i, j, k \in \mathrm{N})
$$


Table 2. FOU data for linguistic terms [52].

\begin{tabular}{cccc}
\hline Words & Normal IT2FSs & Centroids & Mean of Centroids \\
\hline WI & {$[(1.00,1.00,1.7184,2.6165),(1.000,1.0734,1.9266)]$} & {$[1.3105,1.6489]$} & 1.4797 \\
\hline MI & {$[(1.4308,2.35,2.80,3.3968),(2.5172,2.6941,3.0828)]$} & {$[2.2339,2.9247]$} & 2.5793 \\
\hline MpI & {$[(2.1515,3.00,3.85,4.8107),(3.3550,3.5368,3.8278)]$} & {$[2.8388,4.1499]$} & 3.4943 \\
\hline SI & {$[(3.3101,4.25,5.05,6.0107),(4.4136,4.8900,5.0278)]$} & {$[4.0868,5.2602]$} & 4.6735 \\
\hline SpI & {$[(4.6893,5.50,6.20,6.9485),(5.6379,5.8889,6.0621)]$} & {$[5.3207,6.3536]$} & 5.8372 \\
\hline vSI & {$[(5.9686,6.750,7.1,8.2314),(6.7172,6.8889,7.1036)]$} & {$[6.5486,7.4660]$} & 7.0073 \\
\hline vvSI & {$[(7.0136,7.65,8.00,8.7071),(7.5172,7.8125,8.0828)]$} & {$[7.5781,8.0816]$} & 7.8299 \\
\hline EI & {$[(7.0253,8.8624,9.000,9.000),(8.8684,8.9908,9.000)]$} & {$[7.9099,8.9506]$} & 8.4302 \\
\hline
\end{tabular}

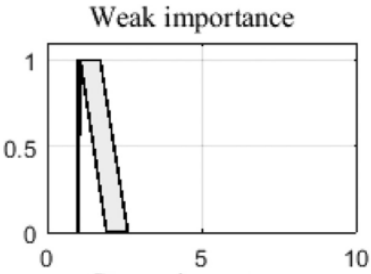

Strong importance
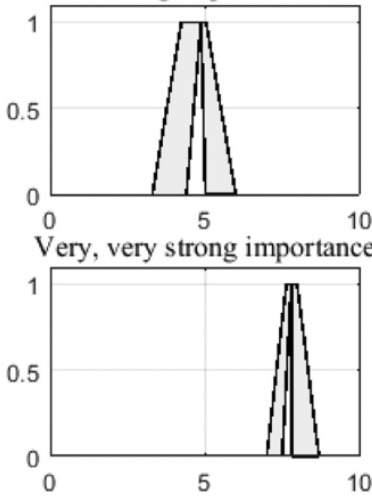

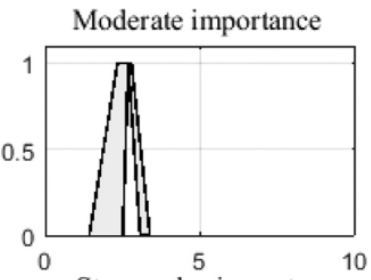

Strong plus importance
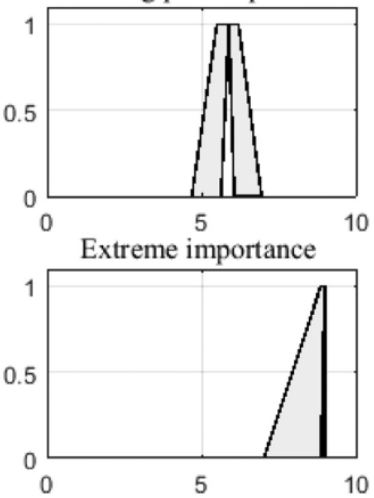

Moderate plus importance

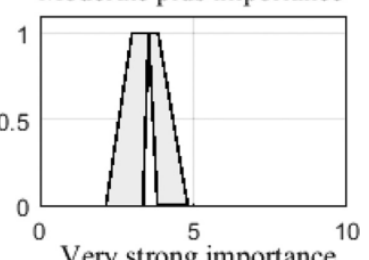

Very strong importance

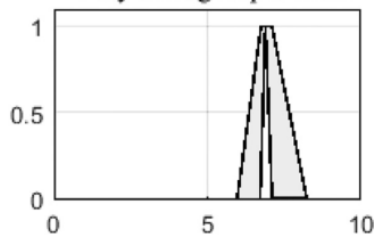

Figure 3. Normal IT2FSs' word models.

Generally, in MCDM problems, it is so essential to determine the criteria weights. The optimal IT2F weighting vector is assumed as $\widetilde{W}=\left(\widetilde{w}_{1}, \widetilde{w}_{2}, n \mathrm{MC} \widetilde{w}_{n}\right)^{T}$. The IT2F weight of the best criteria is shown as $\widetilde{w}_{B}$ for all criteria weights, and $\widetilde{w}_{w}$ is related to the worst criteria. Then, assume the elements in the IT2FBO and IT2FOW vectors. We have $\widetilde{w}_{B} / \widetilde{w}_{j}=\widetilde{A}_{B j}$ and $\widetilde{w}_{j} / \widetilde{w}_{W}=\widetilde{A}_{j w}$, if the IT2FP is completely consistent. Generally, it is difficult to obtain perfectly complete IT2FPs. For obtaining complete consistency, a creative solution is minimizing the maximum absolute gaps between $\left|\widetilde{w}_{B} / \widetilde{w}_{j}=\widetilde{A}_{B j}\right|$ and $\left|\widetilde{w}_{j} / \widetilde{w}_{W}=\widetilde{A}_{j w}\right|$. A normalization process is required to achieve the IT2F criterion weights, and we assume the centroid of the IT2FSs. Accordingly, we develop the following constrained optimization model for obtaining the optimal IT2F weights $\widetilde{W}^{*}=\left(\widetilde{w}_{1}^{*}, \widetilde{w}_{2}^{*}, \widetilde{w}_{n}^{*}\right)^{T}$, 


$$
\begin{gathered}
\underset{j \min }{\max _{j}}\left\{\left|\widetilde{w}_{B} / \widetilde{w}_{j}-\widetilde{A}_{B j}\right|,\left|\widetilde{w}_{j} / \widetilde{w}_{W}-\widetilde{A}_{j w}\right|\right\} \\
\text { s.t. } \\
\sum_{j=1}^{n} C\left(\widetilde{w}_{j}\right)=1 \\
w_{j 1}^{U} \leq w_{j 1}^{L}, w_{j 3}^{L} \leq w_{j 4}^{U} \\
w_{j 1}^{L} \leq w_{j 2}^{L} \leq w_{j 3}^{L} \\
w_{j 1}^{U} \leq w_{j 2}^{U} \leq w_{j 3}^{U} \leq w_{j 4}^{U} \\
w_{j 1}^{U} \geq 0, j=1,2, \ldots, n
\end{gathered}
$$

where $\quad \widetilde{w}_{B}=\left|\left(\widetilde{w}_{B 1}^{U}, \widetilde{w}_{B 2}^{U}, \widetilde{w}_{B 3}^{U}, \widetilde{w}_{B 4}^{U}\right),\left(\widetilde{w}_{B 1}^{L}, \widetilde{w}_{B 2}^{L}, \widetilde{w}_{B 3}^{L}\right)\right|, \quad \widetilde{w}_{j}=\mid\left(\widetilde{w}_{j 1}^{U}, \widetilde{w}_{j 2}^{U}, \widetilde{w}_{j 3}^{U}, \widetilde{w}_{j 4}^{U}\right)$, $\left(\widetilde{w}_{j 1}^{L}, \widetilde{w}_{j 2}^{L}, \widetilde{w}_{j 3}^{L}\right)\left|, \quad \widetilde{w}_{W}=\right|\left(\widetilde{w}_{W 1}^{U}, \widetilde{w}_{W 2}^{U}, \widetilde{w}_{W 3}^{U}, \widetilde{w}_{W 4}^{U}\right),\left(\widetilde{w}_{W 1}^{L}, \widetilde{w}_{W 2}^{L}, \widetilde{w}_{W 3}^{L}\right) \mid$, $\widetilde{A}_{\mathrm{Bj}}=\left|\left(\widetilde{w}_{B, j 1}^{U}, \widetilde{w}_{B, j 2}^{U}, \widetilde{w}_{B, j 3}^{U}, \widetilde{w}_{B, j 4}^{U}\right),\left(\widetilde{w}_{B, j 1}^{L}, \widetilde{w}_{B, j 2}^{L}, \widetilde{w}_{B, j 3}^{L}\right)\right|$, and $\mid\left(\widetilde{w}_{j, W 1}^{U}, \widetilde{w}_{j, W 2}^{U}, \widetilde{w}_{j, W 3}^{U}, \widetilde{w}_{j, W 4}^{U}\right)$, $\left(\widetilde{w}_{j, W 1}^{L}, \widetilde{w}_{j, W 2}^{L}, \widetilde{w}_{j, W 3}^{L}\right)$

In order to avoid achieving multiple optimal solutions [56] from model (2), the maximum absolute gaps between $\left\{\left|\widetilde{w}_{B}-\widetilde{w}_{j} \times \widetilde{A}_{B j}\right|\right\}$ and $\left\{\left|\widetilde{w}_{j}-\widetilde{w}_{W} \times \widetilde{A}_{j w}\right|\right\}$ can be minimized. For minimization, we consider that maximum absolute gap $\widetilde{\delta}^{*}=\left\{\left(\delta^{*}, \delta^{*}, \delta^{*}, \delta^{*}\right),\left(\delta^{*}, \delta^{*}\right.\right.$, $\left.\left.\delta^{*}\right)\right\}$; so, we can replace model (2) by the following model:

$$
\begin{gathered}
\min \delta^{*} s . t .\left|\widetilde{w}_{B 1}^{U}-\widetilde{w}_{j 1}^{U} \widetilde{w}_{B j, 1}^{U}\right| \leq \delta^{*},\left|\widetilde{w}_{B 2}^{U}-\widetilde{w}_{j 2}^{U} \widetilde{w}_{B j, 2}^{U}\right| \leq \delta^{*},\left|\widetilde{w}_{B 3}^{U}-\widetilde{w}_{j 3}^{U} \widetilde{w}_{B j, 3}^{U}\right| \leq \delta^{*}, \\
\left|\widetilde{w}_{B 4}^{U}-\widetilde{w}_{j 4}^{U} \widetilde{w}_{B j, 4}^{U}\right| \leq \delta^{*},\left|\widetilde{w}_{B 1}^{L}-\widetilde{w}_{j 1}^{L} \widetilde{w}_{B j, 1}^{L}\right| \leq \delta^{*},\left|\widetilde{w}_{B 2}^{L}-\widetilde{w}_{j 2}^{L} \widetilde{w}_{B j, 2}^{L}\right| \leq \delta^{*}, \\
\left|\widetilde{w}_{B 3}^{L}-\widetilde{w}_{j 3}^{L} \widetilde{w}_{B j, 3}^{L}\right| \leq \delta^{*},\left|\widetilde{w}_{j 1}^{U}-\widetilde{w}_{W 1}^{U} \widetilde{w}_{j W, 1}^{U}\right| \leq \delta^{*},\left|\widetilde{w}_{j 2}^{U}-\widetilde{w}_{W 2}^{U} \widetilde{w}_{j W, 2}^{U}\right| \leq \delta^{*}, \\
\left|\widetilde{w}_{j 3}^{U}-\widetilde{w}_{W 3}^{U} \widetilde{w}_{j W, 3}^{U}\right| \leq \delta^{*},\left|\widetilde{w}_{j 4}^{U}-\widetilde{w}_{W 4}^{U} \widetilde{w}_{j W, 4}^{U}\right| \leq \delta^{*},\left|\widetilde{w}_{j 1}^{L}-\widetilde{w}_{W 1}^{L} \widetilde{w}_{j W, 1}^{L}\right| \leq \delta^{*}, \\
\left|\widetilde{w}_{j 2}^{L}-\widetilde{w}_{W 2}^{L} \widetilde{w}_{j W, 2}^{L}\right| \leq \delta^{*},\left|\widetilde{w}_{j 3}^{L}-\widetilde{w}_{W 3}^{L} \widetilde{w}_{j W, 3}^{L}\right| \leq \delta^{*}, \sum_{j=1}^{n} C\left(\widetilde{w}_{j}\right)=1 \\
\widetilde{w}_{j 3}^{L} \leq \widetilde{w}_{j 4}^{U} \widetilde{w}_{j 2}^{L} \leq \widetilde{w}_{j 3}^{L} \leq \widetilde{w}_{j 3}^{L}, \widetilde{w}_{j 1}^{U} \leq \widetilde{w}_{j 2}^{U} \leq \widetilde{w}_{j 3}^{U} \leq \widetilde{w}_{j 4}^{U} \widetilde{w}_{j 1}^{U} \geq 0, j=1,2, \ldots, n .
\end{gathered}
$$

The solution space of model (3) is an intersection of linear constraints, one for the sum of the weights and some for the IT2FSs. For achieving a sufficiently large $\widetilde{\delta}^{*}$, the solution space is non-empty; thus, a feasible region must be observed. By solving model (3), we can obtain the optimal weights $\left(\widetilde{w}_{1}, \widetilde{w}_{2} \text {, the } \widetilde{w}_{n}\right)^{T}$ and $\widetilde{\delta}^{*}$. Of course, the crisp weights can be obtained in the following.

\section{Investigating Consistency Ratio in IT2FBWM}

The consistency ratio (CR) is a common and effective indicator to represent the consistency degree in PRs. In this study, the CR index is obtained to evaluate the reliability of the IT2FBWM. As $\widetilde{A}_{B j} \times \widetilde{A}_{j W} \neq \widetilde{A}_{B W}$, the IT2FBWM will be inconsistent. For establishing $\widetilde{A}_{B j} \times \widetilde{A}_{j W}=\widetilde{A}_{B W}$, an IT2FS $\widetilde{\delta}^{*}$ is applied such that $\widetilde{\delta s}=[(\delta, \delta, \delta, \delta),(\delta, \delta, \delta)]$. Thus, the following equation exists:

$$
\left(\widetilde{A}_{B j}-\widetilde{\delta}\right) \times\left(\widetilde{A}_{j W}-\widetilde{\delta}\right)=\widetilde{A}_{B W}+\widetilde{\delta}
$$

Now, since $\widetilde{A}_{B j}=\widetilde{A}_{j W}=\widetilde{A}_{B W}$, we can rewrite this equation as follows:

$$
\left(\widetilde{A}_{B W}-\widetilde{\delta}\right) \times\left(\widetilde{A}_{B W}-\widetilde{\delta}\right)=\widetilde{A}_{B W}+\widetilde{\delta}
$$


Then, the following equation can be resulted from (5):

$$
\widetilde{\delta}^{2}-\left(1^{*}+2 \widetilde{A}_{B W}\right) \widetilde{\delta}+\left(\widetilde{A}_{B W}{ }^{2}-\widetilde{A}_{B W}\right)=0^{*}
$$

in which $1^{*}=[(1,1,1,1),(1,1,1)]$ and $0^{*}=[(0,0,0,0),(0,0,0)]$.

The $\widetilde{\delta}$ can also be shown by a crisp value $\delta$; thus, Equation (6) can change to Equation (7), as below:

$$
\delta^{2}-\left(1+2 \mathrm{C}\left(\widetilde{A}_{B W}\right)\right) \delta+\left(\left(\mathrm{C}\left(\widetilde{A}_{B W}\right)\right)^{2}-\mathrm{C}\left(\widetilde{A}_{B W}\right)=0\right.
$$

By solving the Equation (7), different values of $C\left(\widetilde{A}_{B W}\right)$ can be employed for obtaining the lowest level of consistency and the related maximum possible values $\delta$. These maximum values $\delta$ can be represented as the CI.

As the IT2FPs have the minimum consistency, the $\mathrm{CI}$ has the maximum deviation value. Hence, the difference between the optimal solution $\delta^{*}$ in Equation (3) and the CI should be as large as possible. Extremely, as $\delta^{*}=0$, the deviation in Equation (3) has the minimum value. Thus, the IT2FPs are perfectly consistent. As $\delta^{*}=\mathrm{CI}$, the deviation in Equation (3) has the maximum value; therefore, the IT2FPs have the lowest consistency. Thus, CR is proposed to evaluate the consistency and the reliability degree of the obtained weights:

$$
\mathrm{CR}=\delta^{*} / \mathrm{CI}
$$

\subsection{Second Phase: Interval Type-2 Fuzzy TOPSIS (IT2FTOPSIS)}

This section develops a novel ranking model by the TOPSIS method under an intervalvalued type-2 fuzzy set based on the criteria's weights obtained by IT2FBWM. In addition, a new ranking index is developed with interval-valued fuzzy Hamming distance measure for prioritizing potential alternatives in the assessment process. Therefore, the methodology for the sustainable/resilient supplier selection problem is proposed regarding experts opinions about the value of criteria for each alternative.

The procedure of the proposed methodology is presented under the following steps.

Step 1. Determining the values for criteria by the opinions of experts through linguistic terms according to type-2 fuzzy sets, which are shown as follows.

$$
\left(\overline{\bar{f}}_{i j}\right)_{m \times n}=\left[\left(\overline{\bar{f}}_{i j}\right)^{\gamma 1} *\left(\overline{\bar{f}}_{i j}^{2}\right)^{\gamma 2} * \ldots *\left(\overline{\bar{f}}_{i j}^{k}\right)^{\gamma k}\right] \forall i, j
$$

where " $m$ " is the number of alternatives, " $n$ " is the number of criteria, and " $k$ " is the number of experts. Therefore, $\left(\overline{\bar{f}}_{i j}\right)^{\gamma k}$ shows the value of criterion " $i$ " for the alternative " $j$ " according to the opinion of expert " $k$ ".

Step 2. Constructing the weighted type-2 fuzzy values by multiplying $\left(\overline{\bar{f}}_{i j}\right)_{m \times n}$ by the weights obtained by IT2FBWM $\left(\mathrm{C}\left(\widetilde{w}_{1}^{*}\right)\right)$, resulting in $\overline{\bar{E}}_{i j}$. The multiplication is performed according to Equation (7).

Step 3. The interval-valued type-2 fuzzy positive ideal solution (IVT2F-PIS) and the interval-valued type-2 fuzzy negative ideal solution (IVT2F-NIS) for each criterion are determined as follows.

$$
\begin{gathered}
x_{j}^{+}=\left\{\overline{\bar{E}}_{1}^{+}, \overline{\bar{E}}_{2}^{+}, \ldots, \overline{\bar{E}}_{n}^{+}\right\} \\
E_{j}^{+}\left\{\begin{array}{c}
\left\{\max _{i}\left\{\operatorname{Rank}\left(\overline{\bar{E}}_{i j}\right)\right\}\right\}, \forall \mathrm{R} \\
\left\{\min _{i}\left\{\operatorname{Rank}\left(\overline{\bar{E}}_{i j}\right)\right\}\right\}, \forall \mathrm{R} \prime
\end{array}\right\} \\
x_{j}^{-}=\left\{\overline{\bar{E}}_{1}^{-}, \overline{\bar{E}}_{2}^{-}, \ldots, \overline{\bar{E}}_{n}^{-}\right\}
\end{gathered}
$$




$$
E_{j}^{-}\left\{\begin{array}{c}
\left\{\min _{i}\left\{\operatorname{Rank}\left(\overline{\bar{E}}_{i j}\right)\right\}\right\}, \forall \mathrm{R} \\
\left\{\max _{i}\left\{\operatorname{Rank}\left(\overline{\bar{E}}_{i j}\right)\right\}\right\}, \forall \mathrm{R} \prime
\end{array}\right\}
$$

where $\mathrm{R}$ and $\mathrm{R} /$ define the sets of benefit criteria and cost criteria, respectively.

Step 4. Calculate the distance values among weighted normalized IVT2F, IVT2F-PIS, and IVT2F-NIS regarding each criterion as follows:

$$
\begin{gathered}
\varphi_{i}^{+}=\sqrt{\sum_{i=1}^{m} \sum_{j=1}^{n}\left(\left(\operatorname{Rank}\left(\overline{\bar{E}}_{i j}\right)-\overline{\bar{E}}_{j}^{+}\right)^{2}\right)} \forall i \\
\varphi_{i}^{-}=\sqrt{\sum_{i=1}^{m} \sum_{j=1}^{n}\left(\left(\operatorname{Rank}\left(\overline{\bar{E}}_{i j}\right)-\overline{\bar{E}}_{j}\right)^{2}\right)} \forall i
\end{gathered}
$$

Step 5. Then, the interval type-2 fuzzy relative closeness coefficient $\left(\mathrm{CC}_{i}\right)$ of every alternative is calculated by IVT2F-Hamming distance measure as follows [57].

$$
\mathrm{CC}_{i}=\sum_{i=1}^{m}\left(\varphi_{i}^{-}-\frac{1}{m} \sum_{i=1}^{m} \varphi_{i}^{-}\right)+\sum_{i=1}^{m}\left(\varphi_{i}^{+}-\frac{1}{m} \sum_{i=1}^{m} \varphi_{i}^{+}\right) / \sqrt{\sum_{i=1}^{m}\left(\varphi_{i}^{-}-\frac{1}{m} \sum_{i=1}^{m} \varphi_{i}^{-}\right)}+\sqrt{\sum_{i=1}^{m}\left(\varphi_{i}^{+}-\frac{1}{m} \sum_{i=1}^{m} \varphi_{i}^{+}\right)}
$$

Step 6. Rank the alternatives by increasing sorting of $\mathrm{CC}_{i}$.

\section{An Empirical Case Study}

Nowadays, the topic of resiliency is getting attention in many fields and industries (e.g., the construction industry, Electrical manufacturing, Hospitals, etc.) since unpredictable events may occur in different phases. The managers must be prepared to handle these sudden events at each moment. Resiliency is vital in the construction industry because of uncertainties in different sections, including materials, equipment, human resources, climate, etc. Therefore, resilient management is necessary for selecting the best supplier of raw materials. This study aimed to select the most resilient supplier for "Atieh Sazan" Co., a major construction company in Iran. This company has almost 12 years of work experience and was in charge of many large construction projects in Iran to establish transport networks and routes (land, rail, air, and sea). This company seeks to select the best supplier for supplying the required cement in its projects in terms of resilient criteria. In this regard, there are four candidates for supplements. The candidates are supplier Hesaraki (Tehran, Iran), supplier Siman Sepahan (Isfahan, Iran), supplier Ilgoli (Tabriz, Iran), and supplier Zarif (Mashhad, Iran).

As mentioned before, the resilient criteria chosen from the previous literature were presented to the project experts to be surveyed. The experts included four university professors in the field of construction and four experts who have a minimum of 15 years of operational experience in the field of construction projects and supplying materials. The result of the survey and the final selected criteria with minimum average points of 7 (Likert scales of 1-9) are presented in Table 3:

Table 3. Final selected resilient criteria for use in the model.

\begin{tabular}{ccr}
\hline Symbol & Criteria & Definition \\
\hline$C_{1}$ & Responsiveness & The ability for quickly reacting or responding to customer \\
requirements [55]
\end{tabular}


Table 3. Cont.

\begin{tabular}{ccc}
\hline Symbol & Criteria & Definition \\
\hline$C_{7}$ & Eco-design & $\begin{array}{r}\text { Suitable Design for resource efficiency, products' reuse, recovery } \\
\text { of materials, reduction or elimination of hazardous materials, and } \\
\text { minimizing embodied energy [48] }\end{array}$ \\
\hline$C_{8}$ & Redundancy & $\begin{array}{r}\text { The strategic and selective usage of spare capacity and inventory, } \\
\text { which can be used to handle disruptions, e.g., spare stocks, } \\
\text { multiple suppliers, and extra facilities [49] }\end{array}$ \\
\hline$C_{9}$ & $\begin{array}{c}\text { Human resource } \\
\text { management }\end{array}$ & $\begin{array}{c}\text { Training the staff for handling dangerous events and creating the } \\
\text { multi-task groups [49] }\end{array}$ \\
\hline
\end{tabular}

\subsection{First Phase: IT2FBWM}

In the first step, in order to obtain the weight of the criteria $\left(C_{1}, C_{2}, C_{3}, \ldots, C_{9}\right)$, the best and worst criteria were chosen by consensus of the experts; then, the BWLRVs were specified regarding the scales of 1-9. Tables 4 and 5 represent the preference degrees according to the experts' opinions in the form of linguistic terms in Table 2.

Table 4. Comparison of the best criteria to all the criteria.

\begin{tabular}{ccccccccccc}
\hline Best-to-Others & $C_{1}$ & $C_{2}$ & $C_{3}$ & $C_{4}$ & $C_{5}$ & $C_{6}$ & $C_{7}$ & $C_{8}$ & $C_{9}$ \\
\hline$C_{3}$ & $\mathrm{VS}$ & $\mathrm{MI}$ & $\mathrm{EI}$ & $\mathrm{WI}$ & $\mathrm{SP}$ & $\mathrm{SI}$ & $\mathrm{MP}$ & $\mathrm{EX}$ & $\mathrm{VVS}$ \\
\hline
\end{tabular}

Table 5. Comparison of all the criteria to the worst criteria.

\begin{tabular}{ccccccccccc}
\hline Others-to-Worst & $C_{1}$ & $C_{2}$ & $C_{3}$ & $C_{4}$ & $C_{5}$ & $C_{6}$ & $C_{7}$ & $C_{8}$ & $C_{9}$ \\
\hline$C_{9}$ & SI & VS & VVS & EX & WI & MI & SP & MP & EI \\
\hline
\end{tabular}

Therefore, IT2FBO and IT2FOW vectors can be shown as follows:

$$
\left.\begin{array}{c}
\widetilde{A}_{B}\left\{\begin{array}{c}
{[(5.9686,6.750,7.1,8.2314)(6.7172,6.8889,7.1036)]} \\
{[(1.4308,2.35,2.80,3.3068)(2.5172,2.6941,3.0828)]} \\
{[(1.000,1.000,1.000,1.000)(1.000,1.000,1.000)]} \\
{[(1.00,1.00,1.7184,2.6165)(1.000,1.0734,1.9266)]} \\
{[(4.6893,5.50,6.20,6.9485)(5.6379,5.8889,6.0621)]} \\
{[(3.3101,4.25,5.05,6.0107)(4.4136,4.8900,5.0278)]} \\
{[(2.1515,3.00,3.85,4.8107)(3.3550,3.5368,3.8278)]} \\
{[(7.0253,8.8624,9.000,9.000)(8.8684,8.9908,9.000)]} \\
{[(7.0136,7.65,8.00,8.7070)(7.5172,7.8125,8.0828)]}
\end{array}\right.
\end{array}\right\}
$$

In order to obtain the optimal IT2F criteria weights, we constructed the optimization model based on Equation (3) and using IT2F values in Tables 3 and 4.

After solving Equation (3), the optimal IT2F weights of the nine criteria were obtained as follows:

$$
\begin{aligned}
& \widetilde{w}_{1}^{*}=[(0.0792,0.0792,0.0799,0.0799),(0.0792,0.0792,0.0803)] \\
& \widetilde{w}_{2}^{*}=[(0.1653,0.1653,0.1653,0.1687),(0.1653,0.1653 .0 .1685)] \\
& \widetilde{w}_{3}^{*}=[(0.0561,0.0561,0.0582,0.0582),(0.0561,0.0561,0.0585)] \\
& \widetilde{w}_{4}^{*}=[(0.0488,0.0488,0.0509,0.0509),(0.0488,0.0488,0.0516)] \\
& \widetilde{w}_{5}^{*}=[(0.0593,0.0593,0.0601,0.0601),(0.0593,0.0598,0.0611)] \\
& \widetilde{w}_{6}^{*}=[(0.0761,0.0761,0.0768,0.0768),(0.0761,0.0763,0.0774)] \\
& \widetilde{w}_{7}^{*}=[(0.0753,0.0753,0.0786,0.0789),(0.0753,0.0753,0.0788)] \\
& \widetilde{w}_{7}^{*}=[(0.0753,0.0753,0.0786,0.0789),(0.0753,0.0753,0.0788)]
\end{aligned}
$$


$\widetilde{w}_{8}^{*}=[(0.0587,0.0587,0.0587,0.0587),(0.0587,0.0587,0.0587)]$

$\widetilde{w}_{9}^{*}=[(0.0309,0.0309,0.0316,0.0316),(0.0309,0.0309,0.0319)]$

Then, the crisp weights of the nine criteria were calculated, as below in Table 6 .

Table 6. Crisp weights of the criteria.

\begin{tabular}{cccccccccc}
\hline Criteria & $\mathrm{C}\left(\tilde{w}_{1}^{*}\right)$ & $\mathrm{C}\left(\tilde{w}_{2}^{*}\right)$ & $\mathrm{C}\left(\tilde{w}_{3}^{*}\right)$ & $\mathrm{C}\left(\tilde{w}_{4}^{*}\right)$ & $\mathrm{C}\left(\tilde{w}_{5}^{*}\right)$ & $\mathrm{C}\left(\tilde{w}_{6}^{*}\right)$ & $\mathrm{C}\left(\tilde{w}_{7}^{*}\right)$ & $\mathrm{C}\left(\tilde{w}_{8}^{*}\right)$ & $\mathrm{C}\left(\tilde{w}_{9}^{*}\right)$ \\
\hline Value & 0.0792 & 0.1653 & 0.0561 & 0.0488 & 0.0593 & 0.0761 & 0.0753 & 0.0587 & 0.0309 \\
\hline
\end{tabular}

\subsection{Second Phase: IT2FTOPSIS}

After obtaining the crisp weights of the nine criteria, this study sought to rank the potential suppliers by an improved TOPSIS method in an IT2F environment. Four candidates including Hesaraki (Tehran), Siman Sepahan (Isfahan), Ilgoli (Tabriz), and Zarif (Mashhad) $\left(A_{1}, A_{2}, A_{3}, A_{4}\right.$, respectively) for supplying the raw materials were evaluated based on the selected nine criteria and the opinions of four experts. (It should be noted that, in this phase, the four experts with a minimum of 15 years of operational experience were involved in defining the importance of criteria.) (Table 2).

In the first step, the linguistic variables for rating the potential candidates were defined based on IT2FS, that are shown in Table 7, as follows.

Table 7. Linguistic variables related to type-2 fuzzy sets.

\begin{tabular}{cc}
\hline Linguistic Terms & Type-2 Fuzzy Scales \\
\hline Very low (VL) & $((0,0,0,1 ; 1,1),(0,0,0,1 ; 1,1))$ \\
Low (L) & $((0,1,1,3 ; 1,1),(0,1,1,3 ; 1,1))$ \\
Medium low (ML) & $((1,3,3,5 ; 1,1),(1,3,3,5 ; 1,1))$ \\
Medium (M) & $((3,5,5,7 ; 1,1),(3,5,5,7 ; 1,1))$ \\
Medium high (MH) & $((5,7,7,9 ; 1,1),(5,7,7,9 ; 1,1))$ \\
High (H) & $((7,9,9,10 ; 1,1),(7,9,9,10 ; 1,1))$ \\
Very high (VH) & $((9,10,10,10 ; 1,1),(9,10,10,10 ; 1,1))$ \\
\hline
\end{tabular}

Then, the relative importance of the criteria for the alternatives was determined based on experts' opinions, which are shown in Table 8.

Table 8. The linguistic assessment specified by experts.

\begin{tabular}{|c|c|c|c|c|c|}
\hline \multirow[t]{2}{*}{ Main Criteria } & \multirow[t]{2}{*}{ Alternatives } & \multicolumn{4}{|c|}{ Experts } \\
\hline & & $k_{1}$ & $k_{2}$ & $k_{3}$ & $k_{4}$ \\
\hline \multirow{4}{*}{$C_{1}$} & $A_{1}$ & $M L$ & $M H$ & $\mathrm{VH}$ & $M$ \\
\hline & $A_{2}$ & $L$ & $M H$ & $M$ & $M$ \\
\hline & $A_{3}$ & $M L$ & $H$ & $M H$ & $M$ \\
\hline & $A_{4}$ & $L$ & $H$ & $M$ & $M$ \\
\hline \multirow{4}{*}{$C_{2}$} & $A_{1}$ & $M L$ & $H$ & $M$ & $L$ \\
\hline & $A_{2}$ & $M L$ & $H$ & $H$ & $L$ \\
\hline & $A_{3}$ & $H$ & VH & $M$ & $M$ \\
\hline & $A_{4}$ & $H$ & $V H$ & $V H$ & $M$ \\
\hline \multirow{4}{*}{$C_{3}$} & $A_{1}$ & $M H$ & $H$ & $M L$ & $M L$ \\
\hline & $A_{2}$ & $M H$ & $H$ & $M L$ & $M L$ \\
\hline & $A_{3}$ & $H$ & $H$ & $H$ & $M L$ \\
\hline & $A_{4}$ & $H$ & $H$ & $V H$ & $M L$ \\
\hline
\end{tabular}


Table 8. Cont.

\begin{tabular}{|c|c|c|c|c|c|}
\hline \multirow[t]{2}{*}{ Main Criteria } & \multirow{2}{*}{$\begin{array}{c}\text { Alternatives } \\
\qquad A_{1}\end{array}$} & \multicolumn{4}{|c|}{ Experts } \\
\hline & & $M H$ & $M$ & $\mathrm{VH}$ & $M H$ \\
\hline \multirow{3}{*}{$C_{4}$} & $A_{2}$ & $M H$ & $M L$ & $H$ & $M L$ \\
\hline & $A_{3}$ & $M H$ & $M$ & $V H$ & $M$ \\
\hline & $A_{4}$ & $M H$ & $M L$ & $H$ & $M L$ \\
\hline \multirow{4}{*}{$C_{5}$} & $A_{1}$ & $H$ & $M$ & $M$ & $H$ \\
\hline & $A_{2}$ & $M$ & $M$ & $\mathrm{VH}$ & $H$ \\
\hline & $A_{3}$ & $H$ & $M$ & $H$ & $V H$ \\
\hline & $A_{4}$ & $M$ & $M$ & $V H$ & $V H$ \\
\hline \multirow{4}{*}{$C_{6}$} & $A_{1}$ & $V L$ & $M$ & $M H$ & $M L$ \\
\hline & $A_{2}$ & $M L$ & $M L$ & MH & $M H$ \\
\hline & $A_{3}$ & $M L$ & $M$ & $M$ & $M L$ \\
\hline & $A_{4}$ & $V L$ & $M L$ & $M$ & $\mathrm{MH}$ \\
\hline \multirow{4}{*}{$C_{7}$} & $A_{1}$ & $M L$ & $V L$ & $M L$ & $L$ \\
\hline & $A_{2}$ & $M L$ & $M L$ & $L$ & $M L$ \\
\hline & $A_{3}$ & $M L$ & $V L$ & $L$ & $V L$ \\
\hline & $A_{4}$ & $M L$ & $M L$ & $M L$ & $L$ \\
\hline \multirow{4}{*}{$C_{8}$} & $A_{1}$ & $H$ & $M L$ & $H$ & $M L$ \\
\hline & $A_{2}$ & $\mathrm{VH}$ & $M$ & $H$ & $H$ \\
\hline & $A_{3}$ & $V H$ & $M$ & $H$ & $V H$ \\
\hline & $A_{4}$ & $H$ & $M L$ & $H$ & $H$ \\
\hline \multirow{4}{*}{$C_{9}$} & $A_{1}$ & $\mathrm{MH}$ & $M$ & $M$ & $M H$ \\
\hline & $A_{2}$ & $M$ & $H$ & $M$ & $M$ \\
\hline & $A_{3}$ & $M H$ & $H$ & $H$ & $H$ \\
\hline & $A_{4}$ & $M H$ & $M$ & $M$ & $M H$ \\
\hline
\end{tabular}

These linguistic terms should be transformed to the IT2FS, according to Table 7. According to step 2 in the second phase, the weighted normalized decision matrix was developed based on the obtained criteria weight in the previous phase, as represented in Table 9. The results were named as $\overline{\bar{E}}_{i j}$ (for the criterion " $i$ " and the alternative " $j$ ").

Then, the aggregated interval type-2 fuzzy decision matrix $\overline{\bar{E}}_{i j}$ for each criterion can be shown as follows in Table 10. 
Table 9. Weighted normalized type-2 fuzzy-decision matrix.

\begin{tabular}{|c|c|c|c|c|c|}
\hline \multirow[t]{2}{*}{ Main Criteria } & \multirow[t]{2}{*}{ Alternatives } & \multicolumn{4}{|c|}{ Experts } \\
\hline & & $k_{1}$ & $k_{2}$ & $k_{3}$ & $k_{4}$ \\
\hline \multirow{4}{*}{$C_{1}$} & $A_{1}$ & $\begin{array}{l}((1.8,2.8,2.8,4.5 ; 1,1) \\
(2.4,3.5,3.5,4.9 ; 1,1))\end{array}$ & $\begin{array}{r}((3.6,5.2,5.2,7 ; 1,1) \\
(3.9,5.4,5.4,7.5 ; 1,1))\end{array}$ & $\begin{array}{c}((5.9,8.4,8.4,10.3 ; 1,1),(6.7 \\
8.9,8.9,10.6 ; 1,1))\end{array}$ & $\begin{array}{l}((3.2,5.3,5.3,6.9 ; 1,1) \\
(4.5,5.7,5.7,7.3 ; 1,1))\end{array}$ \\
\hline & $A_{2}$ & $\begin{array}{l}((1.3,2.6,2.6,4.3 ; 1,1) \\
(2.1,2.9,2.9,4.2 ; 1,1))\end{array}$ & $\begin{array}{r}((3.6,5.2,5.2,7 ; 1,1) \\
(3.9,5.4,5.4,7.5 ; 1,1))\end{array}$ & $\begin{array}{c}((3.2,5.3,5.3,6.9 ; 1,1),(4.5 \\
5.7,5.7,7.3 ; 1,1))\end{array}$ & $\begin{array}{l}((3.2,5.3,5.3,6.9 ; 1,1) \\
(4.5,5.7,5.7,7.3 ; 1,1))\end{array}$ \\
\hline & $A_{3}$ & $\begin{array}{l}((1.8,2.8,2.8,4.5 ; 1,1) \\
(2.4,3.5,3.5,4.9 ; 1,1))\end{array}$ & $\begin{array}{l}((4.9,7.9,7.9,9.2 ; 1,1) \\
(5.2,8.3,8.3,9.4 ; 1,1))\end{array}$ & $\begin{array}{c}((3.6,5.2,5.2,7 ; 1,1),(3.9 \\
\quad 5.4,5.4,7.5 ; 1,1))\end{array}$ & $\begin{array}{l}((3.2,5.3,5.3,6.9 ; 1,1) \\
(4.5,5.7,5.7,7.3 ; 1,1))\end{array}$ \\
\hline & $A_{4}$ & $\begin{array}{l}((1.3,2.6,2.6,4.3 ; 1,1) \\
(2.1,2.9,2.9,4.2 ; 1,1))\end{array}$ & $\begin{array}{l}((4.9,7.9,7.9,9.2 ; 1,1) \\
(5.2,8.3,8.3,9.4 ; 1,1))\end{array}$ & $\begin{array}{c}((3.2,5.3,5.3,6.9 ; 1,1),(4.5 \\
5.7,5.7,7.3 ; 1,1))\end{array}$ & $\begin{array}{l}((3.2,5.3,5.3,6.9 ; 1,1) \\
(4.5,5.7,5.7,7.3 ; 1,1))\end{array}$ \\
\hline \multirow{4}{*}{$C_{2}$} & $A_{1}$ & $\begin{array}{l}((2.5,3.8,3,8,5.4 ; 1,1) \\
(2.9,4.8,4.8,5.9 ; 1,1))\end{array}$ & $\begin{array}{l}((7.6,8.2,8.2,11.7 ; 1,1) \\
(7.9,8.6,8.6,13.6 ; 1,1))\end{array}$ & $\begin{array}{c}((1.7,3.8,3,8,5.4 ; 1,1),(1.9 \\
\quad 4.1,4.1,5.9 ; 1,1))\end{array}$ & $\begin{array}{l}((1.7,3.8,3,8,5.4 ; 1,1) \\
(1.9,4.1,4.1,5.9 ; 1,1))\end{array}$ \\
\hline & $A_{2}$ & $\begin{array}{l}((2.5,3.8,3,8,5.4 ; 1,1) \\
(2.9,4.8,4.8,5.9 ; 1,1))\end{array}$ & $\begin{array}{l}((7.6,8.2,8.2,11.7 ; 1,1), \\
(7.9,8.6,8.6,13.6 ; 1,1))\end{array}$ & $\begin{array}{c}((1.7,3.8,3,8,5.4 ; 1,1),(1.9 \\
\quad 4.1,4.1,5.9 ; 1,1))\end{array}$ & $\begin{array}{l}((1.7,3.8,3,8,5.4 ; 1,1) \\
(1.9,4.1,4.1,5.9 ; 1,1))\end{array}$ \\
\hline & $A_{3}$ & $\begin{array}{l}((7.6,8.2,8.2,11.7 ; 1,1), \\
(7.9,8.6,8.6,13.6 ; 1,1))\end{array}$ & $\begin{array}{l}((7.6,8.2,8.2,11.7 ; 1,1), \\
(7.9,8.6,8.6,13.6 ; 1,1))\end{array}$ & $\begin{array}{l}((7.6,8.2,8.2,11.7 ; 1,1) \\
(7.9,8.6,8.6,13.6 ; 1,1))\end{array}$ & $\begin{array}{l}((1.7,3.8,3,8,5.4 ; 1,1) \\
(1.9,4.1,4.1,5.9 ; 1,1))\end{array}$ \\
\hline & $A_{4}$ & $\begin{array}{l}((7.6,8.2,8.2,11.7 ; 1,1), \\
(7.9,8.6,8.6,13.6 ; 1,1))\end{array}$ & $\begin{array}{l}((7.6,8.2,8.2,11.7 ; 1,1), \\
(7.9,8.6,8.6,13.6 ; 1,1))\end{array}$ & $\begin{array}{c}((8.2,9.7,9.7,10.6 ; 1,1) \\
(8.9,10.7,10.7,11.3 ; 1,1))\end{array}$ & $\begin{array}{l}((1.7,3.8,3,8,5.4 ; 1,1) \\
(1.9,4.1,4.1,5.9 ; 1,1))\end{array}$ \\
\hline \multirow{4}{*}{$C_{3}$} & $A_{1}$ & $\begin{array}{c}((6.4,7.6,7.6,8.6 ; 1,1) \\
(6.9,8,8,9.6 ; 1,1))\end{array}$ & $\begin{array}{l}((7.4,8.8,8.8,9.3 ; 1,1) \\
(7.5,9.4,9.4,9.6 ; 1,1))\end{array}$ & $\begin{array}{c}((4.2,4.8,4.8,5.6 ; 1,1),(4.4 \\
5.2,5.2,5.7 ; 1,1))\end{array}$ & $\begin{array}{l}((4.2,4.8,4.8,5.6 ; 1,1) \\
(4.4,5.2,5.2,5.7 ; 1,1))\end{array}$ \\
\hline & $A_{2}$ & $\begin{array}{l}((6.4,7.6,7.6,8.6 ; 1,1) \\
(6.9,8,8,9.6 ; 1,1))\end{array}$ & $\begin{array}{l}((7.4,8.8,8.8,9.3 ; 1,1) \\
(7.5,9.4,9.4,9.6 ; 1,1))\end{array}$ & $\begin{array}{c}((4.2,4.8,4.8,5.6 ; 1,1),(4.4 \\
5.2,5.2,5.7 ; 1,1))\end{array}$ & $\begin{array}{l}((4.2,4.8,4.8,5.6 ; 1,1) \\
(4.4,5.2,5.2,5.7 ; 1,1))\end{array}$ \\
\hline & $A_{3}$ & $\begin{array}{l}((7.4,8.8,8.8,9.3 ; 1,1) \\
(7.5,9.4,9.4,9.6 ; 1,1))\end{array}$ & $\begin{array}{l}((7.4,8.8,8.8,9.3 ; 1,1) \\
(7.5,9.4,9.4,9.6 ; 1,1))\end{array}$ & $\begin{array}{c}((7.4,8.8,8.8,9.3 ; 1,1),(7.5 \\
9.4,9.4,9.6 ; 1,1))\end{array}$ & $\begin{array}{l}((4.2,4.8,4.8,5.6 ; 1,1) \\
(4.4,5.2,5.2,5.7 ; 1,1))\end{array}$ \\
\hline & $A_{4}$ & $\begin{array}{l}((7.4,8.8,8.8,9.3 ; 1,1) \\
(7.5,9.4,9.4,9.6 ; 1,1))\end{array}$ & $\begin{array}{l}((7.4,8.8,8.8,9.3 ; 1,1) \\
(7.5,9.4,9.4,9.6 ; 1,1))\end{array}$ & $\begin{array}{c}((8.8,9.5,9.5,9.9 ; 1,1),(9.2 \\
9.7,9.7,10.4 ; 1,1))\end{array}$ & $\begin{array}{l}((4.2,4.8,4.8,5.6 ; 1,1) \\
(4.4,5.2,5.2,5.7 ; 1,1))\end{array}$ \\
\hline \multirow{4}{*}{$C_{4}$} & $A_{1}$ & $\begin{array}{r}((6.1,6.4,6.4,7 ; 1,1) \\
(6.4,7.2,7.2,7.8 ; 1,1))\end{array}$ & $\begin{array}{l}((5.4,5.7,5.7,6.7 ; 1,1) \\
(5.6,5.9,5.9,6.9 ; 1,1))\end{array}$ & $\begin{array}{r}((9.8,10.2,10.2,11 ; 1,1) \\
(10.4,11.2,11.2,12 ; 1,1))\end{array}$ & $\begin{array}{c}((6.1,6.4,6.4,7 ; 1,1),(6.4, \\
7.2,7.2,7.8 ; 1,1))\end{array}$ \\
\hline & $A_{2}$ & $\begin{array}{r}((6.1,6.4,6.4,7 ; 1,1) \\
(6.4,7.2,7.2,7.8 ; 1,1))\end{array}$ & $\begin{array}{l}((5.2,5.8,5.8,7.4 ; 1,1) \\
(5.6,6.1,6.1,7.9 ; 1,1))\end{array}$ & $\begin{array}{c}((9.2,9.5,9.5,9.8 ; 1,1),(9.6 \\
10,10,10.8 ; 1,1))\end{array}$ & $\begin{array}{l}((5.2,5.8,5.8,7.4 ; 1,1) \\
(5.6,6.1,6.1,7.9 ; 1,1))\end{array}$ \\
\hline & $A_{3}$ & $\begin{array}{r}((6.1,6.4,6.4,7 ; 1,1) \\
(6.4,7.2,7.2,7.8 ; 1,1)) \\
\end{array}$ & $\begin{array}{l}((5.4,5.7,5.7,6.7 ; 1,1) \\
(5.6,5.9,5.9,6.9 ; 1,1))\end{array}$ & $\begin{array}{r}((9.8,10.2,10.2,11 ; 1,1) \\
(10.4,11.2,11.2,12 ; 1,1))\end{array}$ & $\begin{array}{l}((5.4,5.7,5.7,6.7 ; 1,1) \\
(5.6,5.9,5.9,6.9 ; 1,1))\end{array}$ \\
\hline & $A_{4}$ & $\begin{array}{r}((6.1,6.4,6.4,7 ; 1,1) \\
(6.4,7.2,7.2,7.8 ; 1,1))\end{array}$ & $\begin{array}{l}((5.2,5.8,5.8,7.4 ; 1,1) \\
(5.6,6.1,6.1,7.9 ; 1,1))\end{array}$ & $\begin{array}{c}((9.2,9.5,9.5,9.8 ; 1,1),(9.6 \\
10,10,10.8 ; 1,1))\end{array}$ & $\begin{array}{l}((5.2,5.8,5.8,7.4 ; 1,1) \\
(5.6,6.1,6.1,7.9 ; 1,1))\end{array}$ \\
\hline \multirow{4}{*}{$C_{5}$} & $A_{1}$ & $\begin{array}{l}((9.1,9.5,9.5,9.9 ; 1,1) \\
(9.4,9.7,9.7,10.2 ; 1,1))\end{array}$ & $\begin{array}{l}((8.2,8.4,8.4,8.9 ; 1,1), \\
(8.5,8.7,8.7,9.2 ; 1,1))\end{array}$ & $\begin{array}{c}((8.2,8.4,8.4,8.9 ; 1,1),(8.5 \\
\quad 8.7,8.7,9.2 ; 1,1))\end{array}$ & $\begin{array}{r}((9.1,9.5,9.5,9.9 ; 1,1) \\
(9.4,9.7,9.7,10.2 ; 1,1))\end{array}$ \\
\hline & $A_{2}$ & $\begin{array}{l}((8.2,8.4,8.4,8.9 ; 1,1) \\
(8.5,8.7,8.7,9.2 ; 1,1))\end{array}$ & $\begin{array}{l}((8.2,8.4,8.4,8.9 ; 1,1) \\
(8.5,8.7,8.7,9.2 ; 1,1))\end{array}$ & $\begin{array}{c}((9.5,9.9,9.9,10.3 ; 1,1) \\
(10.3,10.9,10.9,11.3 ; 1,1))\end{array}$ & $\begin{array}{r}((9.1,9.5,9.5,9.9 ; 1,1) \\
(9.4,9.7,9.7,10.2 ; 1,1))\end{array}$ \\
\hline & $A_{3}$ & $\begin{array}{r}((9.1,9.5,9.5,9.9 ; 1,1) \\
(9.4,9.7,9.7,10.2 ; 1,1))\end{array}$ & $\begin{array}{l}((8.2,8.4,8.4,8.9 ; 1,1), \\
(8.5,8.7,8.7,9.2 ; 1,1))\end{array}$ & $\begin{array}{c}((9.1,9.5,9.5,9.9 ; 1,1),(9.4 \\
9.7,9.7,10.2 ; 1,1))\end{array}$ & $\begin{array}{c}((9.5,9.9,9.9,10.3 ; 1,1) \\
(10.3,10.9,10.9,11.3 ; 1,1))\end{array}$ \\
\hline & $A_{4}$ & $\begin{array}{l}((8.2,8.4,8.4,8.9 ; 1,1) \\
(8.5,8.7,8.7,9.2 ; 1,1))\end{array}$ & $\begin{array}{l}((8.2,8.4,8.4,8.9 ; 1,1) \\
(8.5,8.7,8.7,9.2 ; 1,1))\end{array}$ & $\begin{array}{c}((9.5,9.9,9.9,10.3 ; 1,1) \\
(10.3,10.9,10.9,11.3 ; 1,1))\end{array}$ & $\begin{array}{c}((9.5,9.9,9.9,10.3 ; 1,1) \\
(10.3,10.9,10.9,11.3 ; 1,1))\end{array}$ \\
\hline \multirow{4}{*}{$\mathrm{C}_{6}$} & $A_{1}$ & $\begin{array}{l}((2.1,3.2,3.2,3.9 ; 1,1), \\
(2.3,3.5,3.5,3.7 ; 1,1))\end{array}$ & $\begin{array}{l}((5.8,6.7,6.7,7.2 ; 1,1) \\
(6.4,6.7,6.7,8.1 ; 1,1))\end{array}$ & $\begin{array}{c}((6.1,6.5,6.5,6.9 ; 1,1),(6.4 \\
6.8,6.8,7.5 ; 1,1))\end{array}$ & $\begin{array}{l}((4.3,4.8,4.8,5.4 ; 1,1) \\
(4.7,5.5,5.5,5.9 ; 1,1))\end{array}$ \\
\hline & $A_{2}$ & $\begin{array}{l}((4.3,4.8,4.8,5.4 ; 1,1) \\
(4.7,5.5,5.5,5.9 ; 1,1))\end{array}$ & $\begin{array}{l}((4.3,4.8,4.8,5.4 ; 1,1) \\
(4.7,5.5,5.5,5.9 ; 1,1))\end{array}$ & $\begin{array}{c}((6.1,6.5,6.5,6.9 ; 1,1),(6.4 \\
6.8,6.8,7.5 ; 1,1))\end{array}$ & $\begin{array}{l}((6.1,6.5,6.5,6.9 ; 1,1) \\
(6.4,6.8,6.8,7.5 ; 1,1))\end{array}$ \\
\hline & $A_{3}$ & $\begin{array}{l}((4.3,4.8,4.8,5.4 ; 1,1) \\
(4.7,5.5,5.5,5.9 ; 1,1))\end{array}$ & $\begin{array}{l}((5.8,6.7,6.7,7.2 ; 1,1) \\
(6.4,6.7,6.7,8.1 ; 1,1))\end{array}$ & $\begin{array}{c}((5.8,6.7,6.7,7.2 ; 1,1),(6.4 \\
6.7,6.7,8.1 ; 1,1))\end{array}$ & $\begin{array}{l}((4.3,4.8,4.8,5.4 ; 1,1) \\
(4.7,5.5,5.5,5.9 ; 1,1))\end{array}$ \\
\hline & $A_{4}$ & $\begin{array}{l}((2.1,3.2,3.2,3.9 ; 1,1), \\
(2.3,3.5,3.5,3.7 ; 1,1))\end{array}$ & $\begin{array}{l}((4.3,4.8,4.8,5.4 ; 1,1) \\
(4.7,5.5,5.5,5.9 ; 1,1))\end{array}$ & $\begin{array}{c}((5.8,6.7,6.7,7.2 ; 1,1),(6.4 \\
\quad 6.7,6.7,8.1 ; 1,1))\end{array}$ & $\begin{array}{l}((6.1,6.5,6.5,6.9 ; 1,1) \\
(6.4,6.8,6.8,7.5 ; 1,1))\end{array}$ \\
\hline
\end{tabular}


Table 9. Cont.

\begin{tabular}{|c|c|c|c|c|c|}
\hline \multirow[t]{2}{*}{ Main Criteria } & \multirow[t]{2}{*}{ Alternatives } & \multicolumn{4}{|c|}{ Experts } \\
\hline & & $k_{1}$ & $k_{2}$ & $k_{3}$ & $k_{4}$ \\
\hline \multirow{4}{*}{$C_{7}$} & $A_{1}$ & $\begin{array}{l}((4.5,5.3,5.3,5.9 ; 1,1) \\
(5.1,5.5,5.5,6.2 ; 1,1))\end{array}$ & $\begin{array}{c}((1.9,2.3,2.3,3 ; 1,1) \\
(2.3,3.4,3.4,3.6 ; 1,1))\end{array}$ & $\begin{array}{l}((4.5,5.3,5.3,5.9 ; 1,1) \\
(5.1,5.5,5.5,6.2 ; 1,1))\end{array}$ & $\begin{array}{l}((2.5,2.9,2.9,3.3 ; 1,1), \\
(3.3,3.9,3.9,4.4 ; 1,1))\end{array}$ \\
\hline & $A_{2}$ & $\begin{array}{l}((4.5,5.3,5.3,5.9 ; 1,1) \\
(5.1,5.5,5.5,6.2 ; 1,1))\end{array}$ & $\begin{array}{l}((4.5,5.3,5.3,5.9 ; 1,1) \\
(5.1,5.5,5.5,6.2 ; 1,1))\end{array}$ & $\begin{array}{l}((2.5,2.9,2.9,3.3 ; 1,1) \\
(3.3,3.9,3.9,4.4 ; 1,1))\end{array}$ & $\begin{array}{l}((4.5,5.3,5.3,5.9 ; 1,1), \\
(5.1,5.5,5.5,6.2 ; 1,1))\end{array}$ \\
\hline & $A_{3}$ & $\begin{array}{l}((4.5,5.3,5.3,5.9 ; 1,1) \\
(5.1,5.5,5.5,6.2 ; 1,1))\end{array}$ & $\begin{array}{c}((1.9,2.3,2.3,3 ; 1,1) \\
(2.3,3.4,3.4,3.6 ; 1,1))\end{array}$ & $\begin{array}{l}((2.5,2.9,2.9,3.3 ; 1,1) \\
(3.3,3.9,3.9,4.4 ; 1,1))\end{array}$ & $\begin{array}{c}((1.9,2.3,2.3,3 ; 1,1) \\
(2.3,3.4,3.4,3.6 ; 1,1))\end{array}$ \\
\hline & $A_{4}$ & $\begin{array}{l}((4.5,5.3,5.3,5.9 ; 1,1) \\
(5.1,5.5,5.5,6.2 ; 1,1))\end{array}$ & $\begin{array}{l}((4.5,5.3,5.3,5.9 ; 1,1) \\
(5.1,5.5,5.5,6.2 ; 1,1))\end{array}$ & $\begin{array}{l}((4.5,5.3,5.3,5.9 ; 1,1) \\
(5.1,5.5,5.5,6.2 ; 1,1))\end{array}$ & $\begin{array}{l}((2.5,2.9,2.9,3.3 ; 1,1), \\
(3.3,3.9,3.9,4.4 ; 1,1))\end{array}$ \\
\hline \multirow{4}{*}{$C_{8}$} & $A_{1}$ & $\begin{array}{l}((8.1,8.9,8.9,9.2 ; 1,1) \\
\quad(8.3,9,9,9.4 ; 1,1))\end{array}$ & $\begin{array}{l}((5.5,5.9,5.9,6.4 ; 1,1) \\
(5.8,6.5,6.5,6.9 ; 1,1))\end{array}$ & $\begin{array}{l}((8.1,8.9,8.9,9.2 ; 1,1) \\
(8.3,9,9,9.4 ; 1,1))\end{array}$ & $\begin{array}{l}((5.5,5.9,5.9,6.4 ; 1,1), \\
(5.8,6.5,6.5,6.9 ; 1,1))\end{array}$ \\
\hline & $A_{2}$ & $\begin{array}{c}((8.5,9,9,10.2 ; 1,1) \\
(8.7,9.4,9.4,10.7 ; 1,1))\end{array}$ & $\begin{array}{l}((3.5,4.5,4.5,5 ; 1,1) \\
3.5,4.5,4.5,5 ; 1,1))\end{array}$ & $\begin{array}{l}((8.1,8.9,8.9,9.2 ; 1,1) \\
(8.3,9,9,9.4 ; 1,1))\end{array}$ & $\begin{array}{l}((5.5,5.9,5.9,6.4 ; 1,1), \\
(5.8,6.5,6.5,6.9 ; 1,1))\end{array}$ \\
\hline & $A_{3}$ & $\begin{array}{c}((8.5,9,9,10.2 ; 1,1) \\
(8.7,9.4,9.4,10.7 ; 1,1))\end{array}$ & $\begin{array}{l}((3.5,4.5,4.5,5 ; 1,1) \\
3.5,4.5,4.5,5 ; 1,1))\end{array}$ & $\begin{array}{c}((8.1,8.9,8.9,9.2 ; 1,1) \\
(8.3,9,9,9.4 ; 1,1))\end{array}$ & $\begin{array}{l}((3.5,4.5,4.5,5 ; 1,1) \\
3.5,4.5,4.5,5 ; 1,1))\end{array}$ \\
\hline & $A_{4}$ & $\begin{array}{c}((8.1,8.9,8.9,9.2 ; 1,1) \\
(8.3,9,9,9.4 ; 1,1))\end{array}$ & $\begin{array}{l}((5.5,5.9,5.9,6.4 ; 1,1) \\
(5.8,6.5,6.5,6.9 ; 1,1))\end{array}$ & $\begin{array}{c}((8.1,8.9,8.9,9.2 ; 1,1) \\
(8.3,9,9,9.4 ; 1,1))\end{array}$ & $\begin{array}{l}((5.5,5.9,5.9,6.4 ; 1,1), \\
(5.8,6.5,6.5,6.9 ; 1,1))\end{array}$ \\
\hline \multirow{4}{*}{$\mathrm{C}_{9}$} & $A_{1}$ & $\begin{array}{l}((4.9,5.5,5.5,6.1 ; 1,1) \\
(4.9,5.8,5.8,2.1 ; 1,1))\end{array}$ & $\begin{array}{l}((3.4,3.8,3.8,4.1 ; 1,1) \\
(3.9,4.5,4.5,4.8 ; 1,1))\end{array}$ & $\begin{array}{l}((3.4,3.8,3.8,4.1 ; 1,1) \\
(3.9,4.5,4.5,4.8 ; 1,1))\end{array}$ & $\begin{array}{l}((4.9,5.5,5.5,6.1 ; 1,1), \\
(4.9,5.8,5.8,2.1 ; 1,1))\end{array}$ \\
\hline & $A_{2}$ & $\begin{array}{l}((3.4,3.8,3.8,4.1 ; 1,1) \\
(3.9,4.5,4.5,4.8 ; 1,1))\end{array}$ & $\begin{array}{l}((5.8,6.5,6.5,7.1 ; 1,1) \\
(5.9,6.7,6.7,7.4 ; 1,1))\end{array}$ & $\begin{array}{l}((3.4,3.8,3.8,4.1 ; 1,1) \\
(3.9,4.5,4.5,4.8 ; 1,1))\end{array}$ & $\begin{array}{l}((3.4,3.8,3.8,4.1 ; 1,1), \\
(3.9,4.5,4.5,4.8 ; 1,1))\end{array}$ \\
\hline & $A_{3}$ & $\begin{array}{l}((4.9,5.5,5.5,6.1 ; 1,1) \\
(4.9,5.8,5.8,2.1 ; 1,1))\end{array}$ & $\begin{array}{l}((5.8,6.5,6.5,7.1 ; 1,1) \\
(5.9,6.7,6.7,7.4 ; 1,1))\end{array}$ & $\begin{array}{l}((5.8,6.5,6.5,7.1 ; 1,1) \\
(5.9,6.7,6.7,7.4 ; 1,1))\end{array}$ & $\begin{array}{l}((5.8,6.5,6.5,7.1 ; 1,1), \\
(5.9,6.7,6.7,7.4 ; 1,1))\end{array}$ \\
\hline & $A_{4}$ & $\begin{array}{l}((4.9,5.5,5.5,6.1 ; 1,1) \\
(4.9,5.8,5.8,2.1 ; 1,1))\end{array}$ & $\begin{array}{c}(((3.4,3.8,3.8,4.1 ; 1,1) \\
(3.9,4.5,4.5,4.8 ; 1,1))\end{array}$ & $\begin{array}{l}((3.4,3.8,3.8,4.1 ; 1,1) \\
(3.9,4.5,4.5,4.8 ; 1,1))\end{array}$ & $\begin{array}{l}((4.9,5.5,5.5,6.1 ; 1,1), \\
(4.9,5.8,5.8,2.1 ; 1,1))\end{array}$ \\
\hline
\end{tabular}

Table 10. Aggregated interval type-2 fuzzy decision matrix $\overline{\bar{E}}_{i j}$.

\begin{tabular}{|c|c|c|c|c|}
\hline \multirow[t]{2}{*}{ Criteria } & \multicolumn{4}{|c|}{ Alternatives } \\
\hline & $A_{1}$ & $A_{2}$ & $A_{3}$ & $A_{4}$ \\
\hline$C_{1}$ & $\begin{array}{l}((3.2,4.3,4.3,4.8 ; 1,1) \\
(3.4,4.6,4.6,5.4 ; 1,1))\end{array}$ & $\begin{array}{l}((2.1,2.5,2.5,2.8 ; 1,1) \\
(2.4,2.9,2.9,3.4 ; 1,1))\end{array}$ & $\begin{array}{l}((3.6,3.9,3.9,4.3 ; 1,1) \\
(3.9,4.1,4.1,4.7 ; 1,1))\end{array}$ & $\begin{array}{l}((3.3,4.3,4.3,4.8 ; 1,1) \\
(3.5,4.5,5.5,5.4 ; 1,1))\end{array}$ \\
\hline$C_{2}$ & $\begin{array}{l}((2.5,2.9,2.9,3.4 ; 1,1) \\
(2.8,3.4,3.4,4.1 ; 1,1))\end{array}$ & $\begin{array}{l}((2.5,2.9,2.9,3.4 ; 1,1) \\
(2.8,3.4,3.4,4.1 ; 1,1))\end{array}$ & $\begin{array}{c}((5.6,6.2,6.2,7 ; 1,1) \\
(5.9,6.4,6.4,7.3 ; 1,1))\end{array}$ & $\begin{array}{l}((6.2,6.7,6.7,7.2 ; 1,1) \\
(6.8,7.3,7.3,8.2 ; 1,1))\end{array}$ \\
\hline$C_{3}$ & $\begin{array}{l}((5.2,5.5,5.5,5.9 ; 1,1) \\
(5.6,6.1,6.1,6.6 ; 1,1))\end{array}$ & $\begin{array}{c}((5.6,6.2,6.2,7 ; 1,1) \\
(5.8,6.4,6.4,6.7 ; 1,1))\end{array}$ & $\begin{array}{c}((6.4,6.8,6.8,7.2 ; 1,1) \\
(6.7,7,7,7.8 ; 1,1))\end{array}$ & $\begin{array}{l}((7.6,7.9,7.9,8.5 ; 1,1) \\
(7.9,8.3,8.3,9.1 ; 1,1))\end{array}$ \\
\hline$C_{4}$ & $\begin{array}{c}((6.4,7.2,7.2,8 ; 1,1) \\
(6.7,7.2,7.2,7.6 ; 1,1))\end{array}$ & $\begin{array}{c}((6.8,7.3,7.3,7.7 ; 1,1) \\
(7.2,7.7,7.7,8 ; 1,1))\end{array}$ & $\begin{array}{c}((6.4,6.7,6.7,7 ; 1,1) \\
(6.7,7.2,7.2,7.6 ; 1,1))\end{array}$ & $\begin{array}{c}((6,6.8,6.8,7.6 ; 1,1) \\
(6.4,7.1,7.1,7.8 ; 1,1))\end{array}$ \\
\hline$C_{5}$ & $\begin{array}{c}((8.4,8.9,8.9,9.4 ; 1,1) \\
(8.6,9.1,9.1,10 ; 1,1))\end{array}$ & $\begin{array}{l}((8.2,8.7,8.7,9.2 ; 1,1) \\
(8.5,8.8,8.8,9.3 ; 1,1))\end{array}$ & $\begin{array}{c}((8.5,8.9,8.9,9.2 ; 1,1) \\
(8.7,9.3,9.3,10.1 ; 1,1))\end{array}$ & $\begin{array}{r}((9.1,9.5,9.5,9.8 ; 1,1) \\
(9.4,9.9,9.9,10.4 ; 1,1))\end{array}$ \\
\hline$C_{6}$ & $\begin{array}{l}((5.2,5.3,5.3,5.6 ; 1,1) \\
(5.4,5.7,5.7,6.1 ; 1,1))\end{array}$ & $\begin{array}{c}((5.4,5.7,5.7,6.3 ; 1,1) \\
(5.6,6,6,6.5 ; 7,1))\end{array}$ & $\begin{array}{c}((4.7,4.9,4.9,5.3 ; 1,1) \\
(5,5.2,5.2,5.4 ; 1,1))\end{array}$ & $\begin{array}{l}((4.6,4.9,4.9,5.3 ; 1,1) \\
(4.9,5.9,5.9,6.4 ; 1,1))\end{array}$ \\
\hline$C_{7}$ & $\begin{array}{l}((3.7,4.1,4.1,4.3 ; 1,1), \\
(4.1,4.7,4.7,5.3 ; 1,1))\end{array}$ & $\begin{array}{c}((4,4.5,4.5,6 ; 1,1),(4.4 \\
5,5,5.2 ; 1,1))\end{array}$ & $\begin{array}{l}((3.2,3.8,3.8,3.9 ; 1,1) \\
(3.6,4.2,4.2,4.6 ; 1,1))\end{array}$ & $\begin{array}{l}((4.2,4.8,4.8,5.3 ; 1,1) \\
(4.6,5.2,5.2,5.7 ; 1,1))\end{array}$ \\
\hline$C_{8}$ & $\begin{array}{l}((7.1,7.9,7.9,8.2 ; 1,1) \\
(7.5,8.1,8.1,8.7 ; 1,1))\end{array}$ & $\begin{array}{l}((6.5,6.9,6.9,7.6 ; 1,1) \\
(6.8,7.3,7.3,8.1 ; 1,1))\end{array}$ & $\begin{array}{l}((6.2,6.7,6.7,7.4 ; 1,1) \\
(6.4,6.9,6.9,8.2 ; 1,1))\end{array}$ & $\begin{array}{l}((6.9,7.5,7.5,8.5 ; 1,1) \\
(7.3,7.7,7.7,8.1 ; 1,1))\end{array}$ \\
\hline$C_{9}$ & $\begin{array}{l}((3.9,4.5,4.5,5.1 ; 1,1) \\
(4.2,5.3,5.3,5.8 ; 1,1))\end{array}$ & $\begin{array}{l}((4.3,4.7,4.7,5.7 ; 1,1) \\
(4.8,5.5,5.5,6.4 ; 1,1))\end{array}$ & $\begin{array}{l}((5.3,5.7,5.7,5.9 ; 1,1) \\
(5.9,6.3,6.3,6.7 ; 1,1))\end{array}$ & $\begin{array}{l}((3.9,4.5,4.5,5.1 ; 1,1) \\
(4.2,5.3,5.3,5.8 ; 1,1))\end{array}$ \\
\hline
\end{tabular}

In the next step, (IVT2F-PIS) and (IVT2F-NIS) are specified for each criterion based on Equations (10)-(13) in step 3. Results are shown in Table 11. 
Table 11. The values of $E^{+}$and $E^{-}$for each criterion.

\begin{tabular}{cccccccccc}
\hline & $C_{1}$ & $C_{2}$ & $C_{3}$ & $C_{4}$ & $C_{5}$ & $C_{6}$ & $C_{7}$ & $C_{8}$ & $C_{9}$ \\
\hline$E^{+}$ & 6.6542 & 15.0256 & 24.6281 & 29.5288 & 22.8274 & 18.8251 & 10.2804 & 25.2814 & 14.2924 \\
$E^{-}$ & 8.5291 & 22.1173 & 19.5299 & 26.6271 & 35.2681 & 13.724 & 9.2751 & 19.2714 & 11.0052 \\
\hline
\end{tabular}

Finally, the $\varphi_{i}^{+}, \varphi_{i}^{-}$and $C C_{i}$ indices are calculated for each alternative in order to determine the most resilient supplier according to Equations (14)-(16) in steps 4 and 5 (Table 12). As noted before, the alternative with the minimum value of $C C_{i}$ is determined as the ideal solution and the next ranks are specified through ascending order of $C C_{i}$.

Table 12. The values of $\varphi^{+}, \varphi^{-}$, and $C C_{i}$ and the final ranking.

\begin{tabular}{ccccc}
\hline & $\varphi^{+}$ & $\varphi^{-}$ & $C C_{\boldsymbol{i}}$ & Ranking \\
\hline$A_{1}$ & 24.2286 & 8.2361 & 9.2388 & 2 \\
$A_{2}$ & 27.1102 & 19.2854 & 5.2918 & 1 \\
$A_{3}$ & 12.2837 & 37.2835 & 18.2846 & 4 \\
$A_{4}$ & 30.2831 & 14.3918 & 13.3992 & 3 \\
\hline
\end{tabular}

The final results can also be shown through Figure 4 .

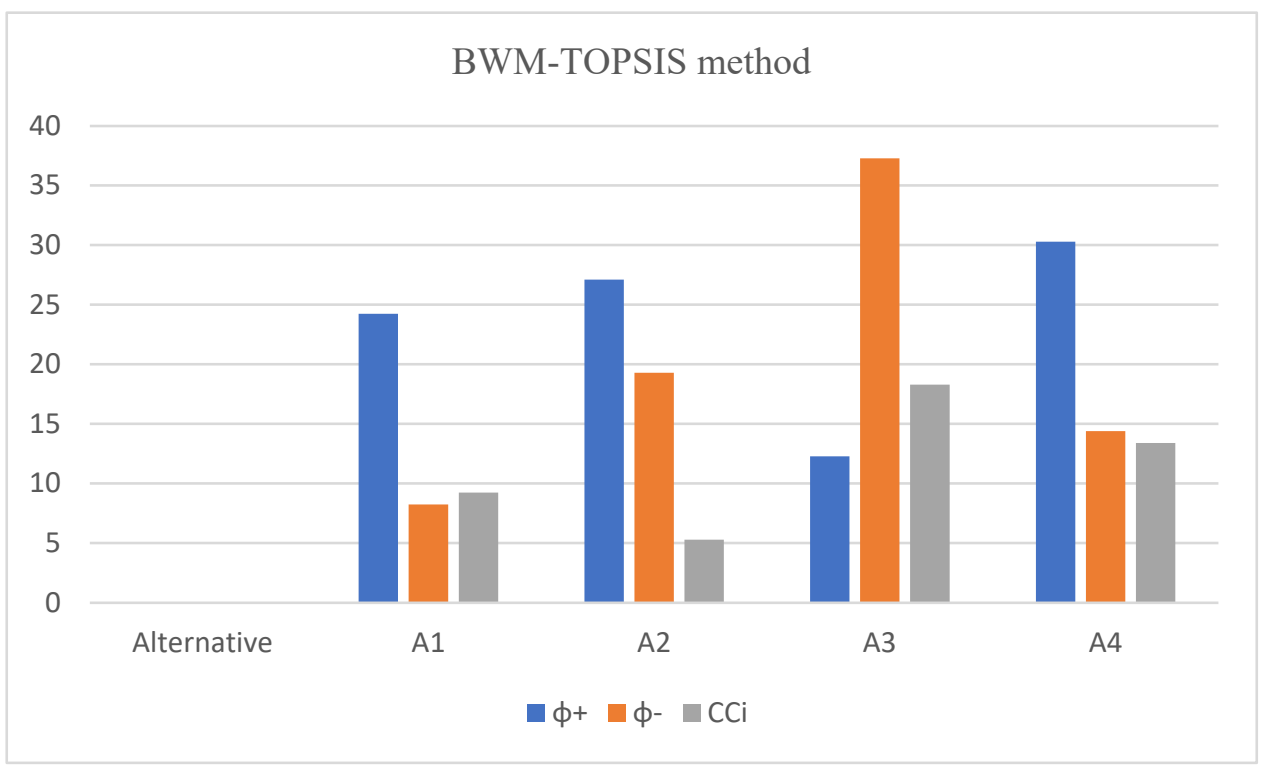

Figure 4. Schematic of final results.

Thus, the final ranking for the potential suppliers was determined, and the alternative " 2 ", i.e., the Siman Sepahan (Isfahan) supplier, was specified as the most resilient supplier. According to this result, it was concluded that the criteria including "Reorganization", "Redundancy", and somewhat "Agility" were relatively the most effective measures for selecting the most resilient supplier in the Iranian Construction Industry. It means that, primarily, those supplier(s) should be selected to integrate resources quickly and reconstruct the organization according to situations. Moreover, the suppliers must be capable of strategic and selective usage of spare capacity and inventory, which can be employed to manage disruptions, e.g., spare stocks and extra facilities. Another point is that the suppliers must have the ability to supply the material and produce a product quickly.

\subsection{Validating the Results}

There are different techniques for validating the decision-making models. In this paper, for validating the robustness of the model, the following two approaches were employed: (1) evaluating the consistency ratio (CR) for BWM [58] and (2) employing two different techniques, including AHP and SAW approaches instead of the BWM method for determining the weights of resilient criteria.

\subsubsection{Determining the CR}

As mentioned before, the CR value must be relatively close to zero to show high consistency in the FBWM process [58]. The value of CR was 0.038, which was computed according to Equations (4)-(8). Therefore, it was concluded that the obtained weights for criteria are reliable, and the BWM model is applicable. 


\subsubsection{Employing Two Different Techniques for Weighting the Criteria}

After obtaining the final results, it is necessary to evaluate the robustness of the ranking process by replacing two other techniques including the AHP and SAW approaches for weighting the criteria instead of the BWM method. These two methods were selected since they have different procedures for weighting the criteria, which are classically common and acceptable for this purpose in literature. Therefore, the results of AHP-TOPSIS and SAW-TOPSIS models can validate the results of the proposed model with a high level of confidence. Figures 5 and 6 represent the final results through AHP-TOPSIS and SAW-TOPSIS approaches in the IT2F environment, respectively.
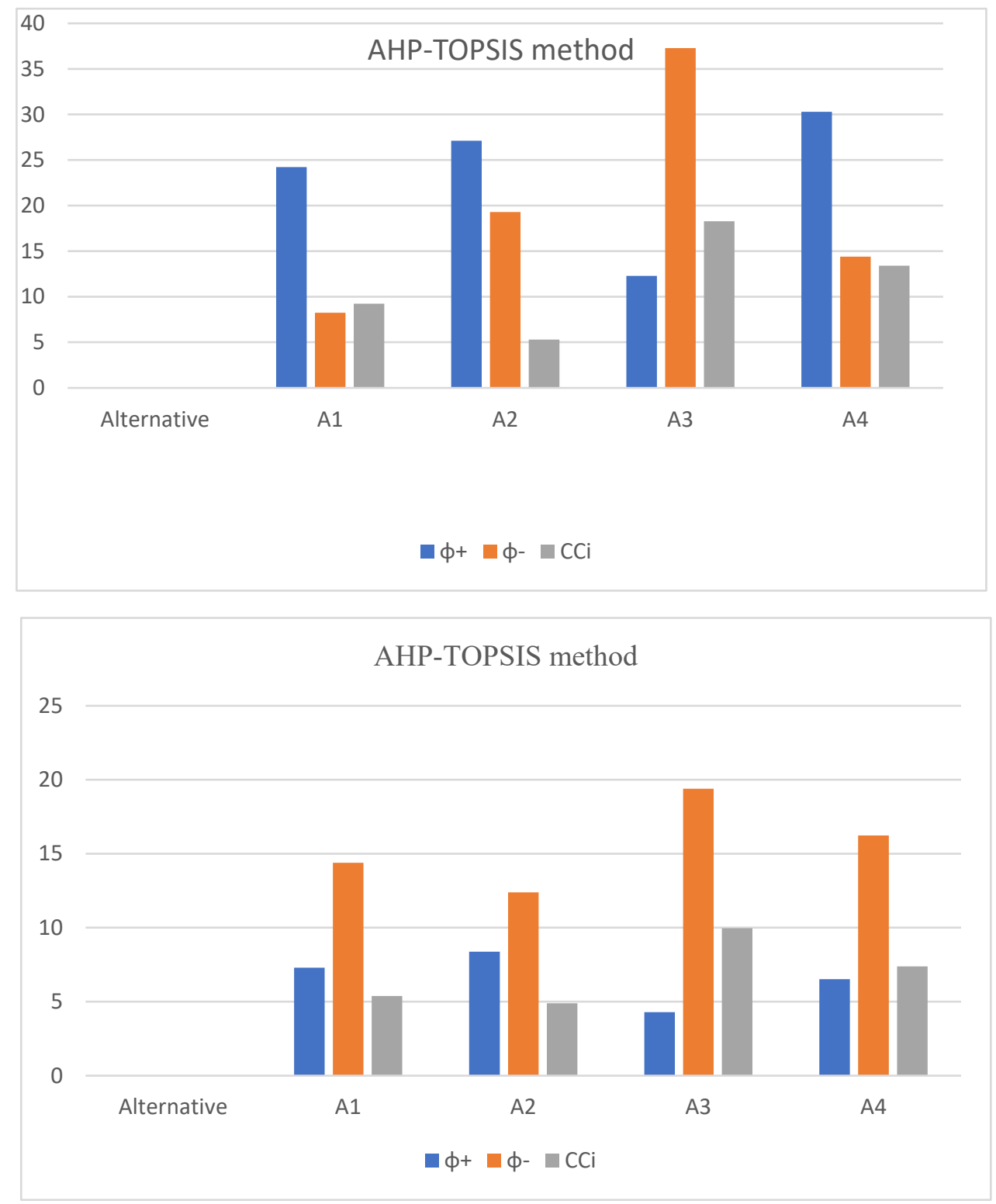

Figure 5. The final results obtained by the IT2F AHP-TOPSIS method. 


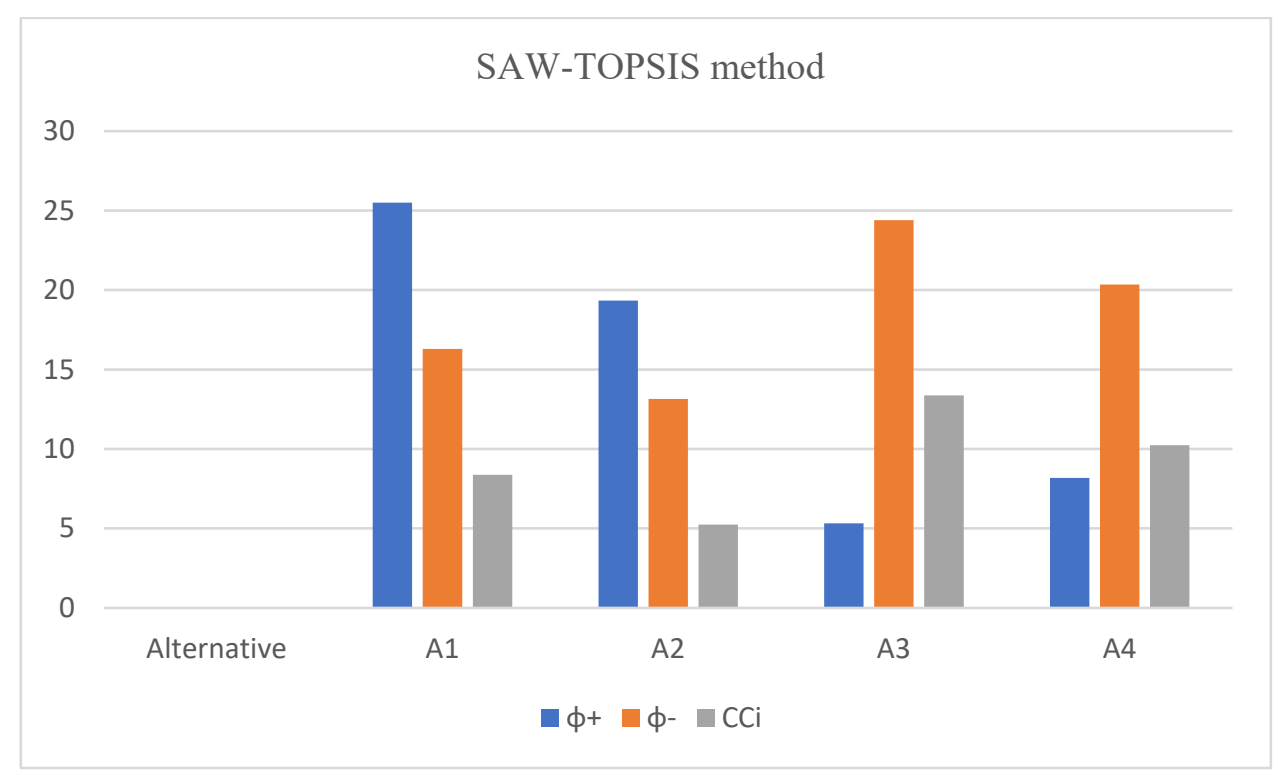

Figure 6. The final results obtained by the IT2F SAW-TOPSIS method.

As shown in Figure 5, the final rankings of the IT2F AHP-TOPSIS method and our method were completely identical. As can be seen in Figure 6, by comparing the SAW-TOPSIS method and ours, only the third and the fourth rankings were not the same and the top-ranking was identical. In other words, it was concluded that, by different techniques for weighting the criteria, the final results were robust. This confirmed the validation of the combined model developed in this study.

\section{Managerial Implications}

Today, many managers and owners of companies in different industries, e.g., the construction industry, must pay attention to supplier selection to gain a competitive advantage in terms of desired factors. Considering resilient factors in decision makings brings competitive advantages to any organization and industry. Resiliency is one of the benefits that must be incorporated with the construction supply chain due to the various unexpected problems that occur at any moment and section. One of the sections is procurement and selecting the right supplier for the materials. Selecting the most resilient supplier is vital in a construction project, and this paper sought to optimize this process.

Resiliency is a relatively new topic in supplier selection, and different methods and techniques have been developed to evaluate and select suppliers according to the determined, resilient criteria. However, selecting the most resilient supplier in an interval type-2 fuzzy environment has not been paid attention to. Thus, this paper evaluated the suppliers based on the resilient criteria to deal with the high level of uncertainty inherited in real cases. Moreover, this study developed the IT2F TOPSIS technique based on Hamming distance to rank the potential suppliers. Generally, the implications of this study are as follows:

- Primarily, the managers in the construction industry or similar fields can employ this model to select the most resilient supplier more appropriately by considering the IT2F environment.

- The model is designed based on experts' opinions, where the information and accountability conditions of sudden events are very sensitive. Thus, it should be pointed out that this decision-making framework can be employed in situations in which sufficient information about the features and capabilities of the suppliers is not available for the experts of projects.

- This study is so helpful for the managers in the (Iranian) construction industry to better understand the concept of resiliency for selecting the best supplier. As mentioned before, they should choose the supplier(s) with more ability for integrating resources quickly and reconstructing the organization according to situations. Moreover, the suppliers must be capable of strategic and selective usage of spare capacity and inventory, which can be employed to manage disruptions, e.g., spare stocks and extra facilities.

- Finally, on the macro scale, this study and the results can help the managers and policy makers adopt the best strategies and policies in supplier selection, which is so important. Generally, and according to the previous points, they can optimize the supplying process, reduce costs, save more time, and remove the bottlenecks, which positively affect the whole project.

\section{Conclusions}

Resilient supplier selection is a relatively new topic in supply chain management, which is placed along with sustainable supplier selection and green supplier selection. However, it is relatively new in comparison with SSS and GSS [59]. In recent years, different companies and industries have sought to gain resilient competencies in their supply chain to overcome their competitors. Determining an appropriate resilient supplier is a major strategic decision with great importance for organizations. Thus, developing the group decision-making methodologies for evaluating the resilient supplier candidates based on various criteria could help decision makers obtain the best 
solution. This study developed a hybrid BWM-TOPSIS method to select the most resilient supplier in an interval type-2 fuzzy environment. This problem is vital because many real cases are consistent with this study, in which a high level of data uncertainty exists.

In the first phase of this model, the resilient evaluative criteria in the construction industry were obtained by reviewing the previous literature and the opinions of the related experts. The IT2FBWM approach was developed to determine the weights of the criteria through the preference degrees according to the experts' opinions in the form of given linguistic terms. Then, in the second phase, an improved interval type- 2 fuzzy TOPSIS method based on Hamming distance measure was developed to rank the potential alternatives. This process was performed through the weights of criteria obtained from the first phase and the relative importance of the alternatives in terms of the evaluative criteria according to the experts' opinions. After determining the rank of alternatives, the decision-making approach was validated. First, the CR value of the IT2FBWM method was computed. The obtained value was close to zero, showing that the obtained weights for criteria are reliable and the BWM model is applicable. Then, instead of the BWM approach, two approaches, including AHP and SAW, were employed to validate the final results. After solving two new decision-making models, it was found that the final ranking did not change and the robustness of the proposed model was confirmed. Therefore, it can be stated that this model can obtain more precise and reliable results for selecting the most resilient supplier in a high level of potential uncertainty and vagueness. We obtained the results with fewer computations in the IT2F environment rather than other similar approaches.

Generally, the managers in the construction industry and other industries with similar supply chains can utilize this decision-making framework for selecting the most resilient supplier, especially because this model is applicable in some situations in which experts have minimum awareness of the issue. They also realize that the criteria of "reorganization", "redundancy", and somewhat "agility" are possibly the most determinant factors for selecting the most resilient supplier in the field of construction or similar fields. This can help them to adopt the most appropriate strategies and policies in the field of supplier selection. Moreover, this model reduces the inherent computational complexity of the IT2F environment by utilizing two applicable techniques, where the results can also be more accurate and reliable so that the managers can employ this framework in many real cases with a high uncertainty level.

In this study, there were two main limitations. The first one was defining and expanding the resilient criteria in the case study for the experts since they are potentially qualitative and hard to quantify. The next one was encoding words into IT2FSs, according to the case study. Moreover, experts responded to the surveys with so much delay. Eventually, there were many obstacles to taking the related information from the company, making this process so time consuming. Finally, future directions can be pointed as follows:

- $\quad$ This decision-making framework can be utilized for resilient supplier selection in other fields and domains and other regions. Without a doubt, before employing this model, the relevant resilient criteria should be formulated and localized according to the specified field and region, respectively.

- $\quad$ This IT2F decision-making model can also be employed to select the best supplier in terms of combined resiliency and sustainability or environmental issues (green supplier selection). Therefore, the supplier selection process will be more comprehensive and reliable.

- In some projects, there may be dependencies between the evaluative criteria. Thus, it is better to use MCDM techniques that evaluate the interrelationships between the criteria, e.g., Analytic Network Process (ANP) and DEMATEL approaches.

- $\quad$ Since most resilient evaluative criteria are qualitative, the experts' opinions are employed to measure their value, which may not be completely accurate. Therefore, if a valid and acceptable approach can be developed to quantify these criteria, the final results will be more reliable.

Author Contributions: Conceptualization, A.F.; Formal analysis, S.A.H.; Funding acquisition, P.S.; Methodology, S.A.H. and A.F.; Project administration, S.H.Z.; Resources, S.S.; Supervision, S.H.Z.; Writing-original draft, S.A.H.; Writing—review \& editing, S.H.Z., P.S. and S.S. All authors have read and agreed to the published version of the manuscript.

Funding: This research received no external funding.

Institutional Review Board Statement: Not applicable.

Informed Consent Statement: Not applicable.

Data Availability Statement: Not applicable.

Conflicts of Interest: The authors declare no conflict of interest. 


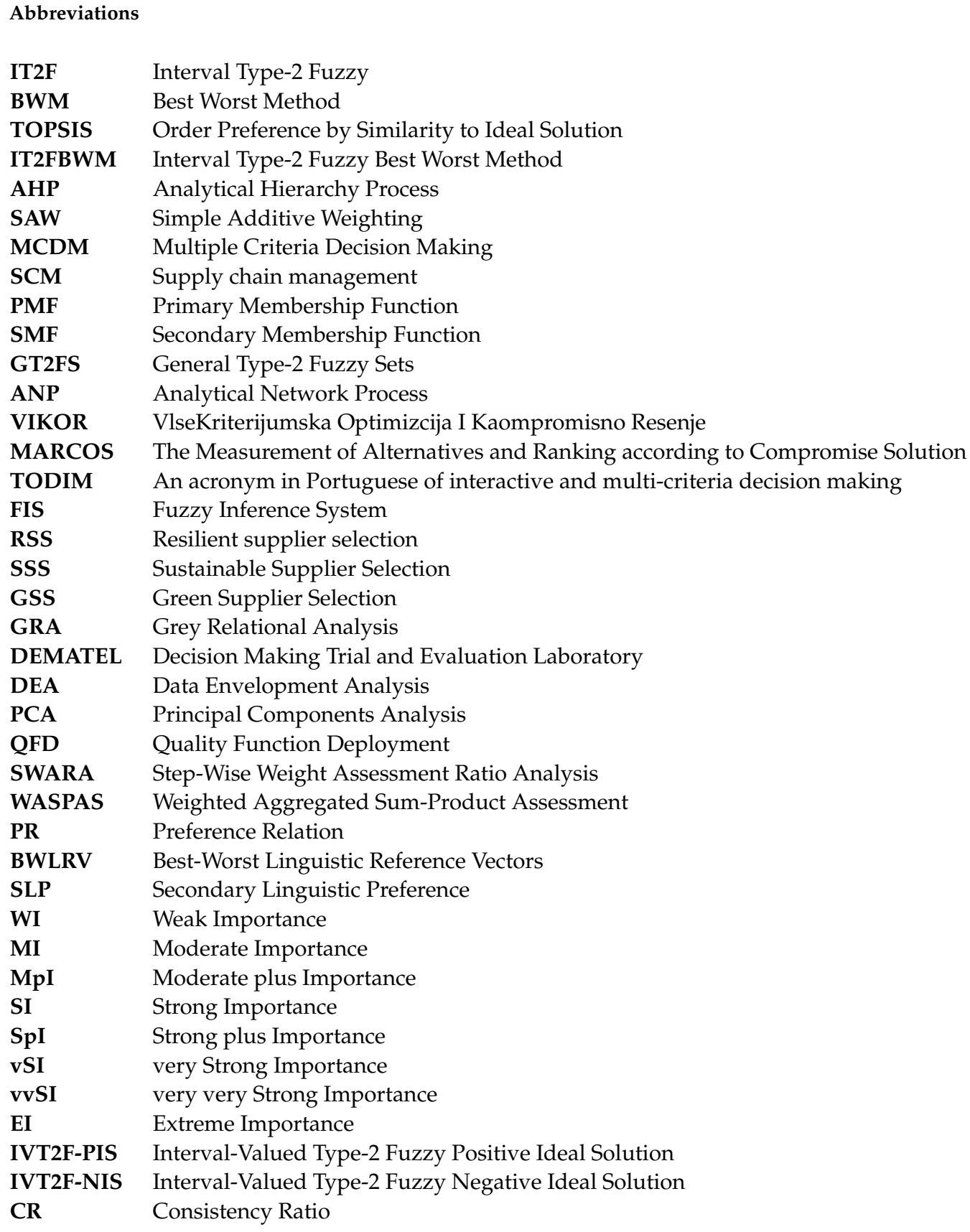

\section{References}

1. Ayyildiz, E.; Gumus, A.T. Interval-valued Pythagorean fuzzy AHP method-based supply chain performance evaluation by a new extension of SCOR model: SCOR 4.0. Complex Intell. Syst. 2020, 7, 559-576. [CrossRef]

2. Gupta, S.; Haq, A.; Ali, I.; Sarkar, B. Significance of multi-objective optimization in logistics problem for multi-product supply chain network under the intuitionistic fuzzy environment. Complex Intell. Syst. 2021, 7, 2119-2139. [CrossRef]

3. Zhang, J.; Li, L.; Zhang, J.; Chen, L.; Chen, G. Private-label sustainable supplier selection using a fuzzy entropy-VIKOR-based approach. Complex Intell. Syst. 2021, 1-18. [CrossRef]

4. Rahimi, M.; Kumar, P.; Moomivand, B.; Yari, G. An intuitionistic fuzzy entropy approach for supplier selection. Complex Intell. Syst. 2021, 7, 1869-1876. [CrossRef]

5. Butt, A.S. Strategies to mitigate the impact of COVID-19 on supply chain disruptions: A multiple case analysis of buyers and distributors. Int. J. Logist. Manag. 2021. ahead-of-print. [CrossRef]

6. Parkouhi, S.V.; Ghadikolaei, A.S. A resilience approach for supplier selection: Using Fuzzy Analytic Network Process and grey VIKOR techniques. J. Clean. Prod. 2017, 161, 431-451. [CrossRef]

7. Hoseini, S.; Fallahpour, A.; Wong, K.; Mahdiyar, A.; Saberi, M.; Durdyev, S. Sustainable Supplier Selection in Construction Industry through Hybrid Fuzzy-Based Approaches. Sustainability 2021, 13, 1413. [CrossRef] 
8. Rashidi, K.; Noorizadeh, A.; Kannan, D.; Cullinane, K. Applying the triple bottom line in sustainable supplier selection: A meta-review of the state-of-the-art. J. Clean. Prod. 2020, 269, 122001. [CrossRef]

9. Davoudabadi, R.; Mousavi, S.M.; Mohagheghi, V.; Vahdani, B. Resilient Supplier Selection Through Introducing a New IntervalValued Intuitionistic Fuzzy Evaluation and Decision-Making Framework. Arab. J. Sci. Eng. 2019, 44, 7351-7360. [CrossRef]

10. Fallahpour, A.; Nayeri, S.; Sheikhalishahi, M.; Wong, K.Y.; Tian, G.; Fathollahi-Fard, A.M. A hyper-hybrid fuzzy decisionmaking framework for the sustainable-resilient supplier selection problem: A case study of Malaysian Palm oil industry. Environ. Sci. Pollut. Res. 2021, 1-21. [CrossRef]

11. Torabi, S.A.; Baghersad, M.; Mansouri, A. Resilient supplier selection and order allocation under operational and disruption risks. Transp. Res. Part E Logist. Transp. Rev. 2015, 79, 22-48. [CrossRef]

12. Sáenz, M.J.; Revilla, E.; Acero, B. Aligning supply chain design for boosting resilience. Bus. Horizons 2018, 61, 443-452. [CrossRef]

13. Mahmoudi, A.; Javed, S.A.; Mardani, A. Gresilient supplier selection through Fuzzy Ordinal Priority Approach: Decision-making in post-COVID era. Oper. Manag. Res. 2021, 1-25. [CrossRef]

14. Hoseini, S.A.; Fallahpour, A.; Wong, K.Y.; Antuchevičienè, J. Developing an integrated model for evaluating r\&d organizations' performance: Combination of dea-anp. Technol. Econ. Dev. Econ. 2021, 27, 970-991. [CrossRef]

15. Taghavi, E.; Fallahpour, A.; Wong, K.Y.; Hoseini, S.A. Identifying and prioritizing the effective factors in the implementation of green supply chain management in the construction industry. Sustain. Oper. Comput. 2021, 2, 97-106. [CrossRef]

16. Amindoust, A. A resilient-sustainable based supplier selection model using a hybrid intelligent method. Comput. Ind. Eng. 2018, 126, 122-135. [CrossRef]

17. Mohammed, A.; Harris, I.; Soroka, A.; Naim, M.; Ramjaun, T.; Yazdani, M. Gresilient supplier assessment and order allocation planning. Ann. Oper. Res. 2020, 296, 335-362. [CrossRef]

18. Fallahpour, A.; Wong, K.Y.; Rajoo, S.; Mardani, A. An Integrated Fuzzy Carbon Management-Based Model for Suppliers' Performance Evaluation and Selection in Green Supply Chain Management. Int. J. Fuzzy Syst. 2019, 22, 712-723. [CrossRef]

19. Bera, A.K.; Jana, D.K.; Banerjee, D.; Nandy, T. Supplier selection using extended IT2 fuzzy TOPSIS and IT2 fuzzy MOORA considering subjective and objective factors. Soft Comput. 2019, 24, 8899-8915. [CrossRef]

20. Baykasoğlu, A.; Gölcük, I. Development of an interval type-2 fuzzy sets based hierarchical MADM model by combining DEMATEL and TOPSIS. Expert Syst. Appl. 2017, 70, 37-51. [CrossRef]

21. Kirac1, K.; Akan, E. Aircraft selection by applying AHP and TOPSIS in interval type-2 fuzzy sets. J. Air Transp. Manag. 2020, 89, 101924. [CrossRef] [PubMed]

22. Zadeh, L.A. The concept of a linguistic variable and its application to approximate reasoning-I. Inf. Sci. 1975, 8, 199-249. [CrossRef]

23. Zbek, A.; Yildiz, A. Digital supplier selection for a garment business using interval type-2 fuzzy topsis. Tekstil Konfeksiyon 2020, 30, 61-72.

24. Ibrahim, H.Z.; Al-Shami, T.M.; Elbarbary, O.G. (3, 2)-Fuzzy Sets and Their Applications to Topology and Optimal Choices. Comput. Intell. Neurosci. 2021, 2021, 1272266. [CrossRef] [PubMed]

25. Ecer, F.; Pamucar, D. Sustainable supplier selection: A novel integrated fuzzy best worst method (F-BWM) and fuzzy CoCoSo with Bonferroni (CoCoSo’B) multi-criteria model. J. Clean. Prod. 2020, 266, 121981. [CrossRef]

26. Rezaei, J. Best-worst multi-criteria decision-making method. Omega 2015, 53, 49-57. [CrossRef]

27. Mahdiyar, A.; Mohandes, S.R.; Durdyev, S.; Tabatabaee, S.; Ismail, S. Barriers to green roof installation: An integrated fuzzy-based MCDM approach. J. Clean. Prod. 2020, 269, 122365. [CrossRef]

28. Yucesan, M.; Gul, M.; Celik, E. A holistic FMEA approach by fuzzy-based Bayesian network and best-worst method Complex Intell. Syst. 2021, 7, 1547-1564. [CrossRef]

29. Li, J.; Niu, L.-L.; Chen, Q.; Wang, Z.-X. Approaches for multicriteria decision-making based on the hesitant fuzzy best-worst method. Complex Intell. Syst. 2021, 7, 2617-2634. [CrossRef]

30. Mei, Y.; Xie, K. An improved TOPSIS method for metro station evacuation strategy selection in interval type-2 fuzzy environment. Clust. Comput. 2017, 22, 2781-2792. [CrossRef]

31. Zolfani, S.H.; Sedaghat, M.; Zavadskas, E.K. Performance Evaluating of Rural ict Centers (Telecenters), Applying Fuzzy Ahp, Saw-G and Topsis Grey, a Case Study in Iran. Technol. Econ. Dev. Econ. 2012, 18, 364-387. [CrossRef]

32. Görener, A.; Ayvaz, B.; Kuşakc1, A.O.; Altınok, E. A hybrid type-2 fuzzy based supplier performance evaluation methodology: The Turkish Airlines technic case. Appl. Soft Comput. 2017, 56, 436-445. [CrossRef]

33. Lee, L.-W.; Chen, S.-M. Fuzzy multiple attributes group decision-making based on the extension of TOPSIS method and interval type-2 fuzzy sets. In Proceedings of the 2008 International Conference on Machine Learning and Cybernetics, Kunming, China, 12-15 July 2008. [CrossRef]

34. Davoudabadi, R.; Mousavi, S.M.; Sharifi, E. An integrated weighting and ranking model based on entropy, DEA and PCA considering two aggregation approaches for resilient supplier selection problem. J. Comput. Sci. 2020, 40, 101074. [CrossRef]

35. Sureeyatanapas, P.; Waleekhajornlert, N.; Arunyanart, S.; Niyamosoth, T. Resilient Supplier Selection in Electronic Components Procurement: An Integration of Evidence Theory and Rule-Based Transformation into TOPSIS to Tackle Uncertain and Incomplete Information. Symmetry 2020, 12, 1109. [CrossRef]

36. Mansory, A.; Nasiri, A.; Mohammadi, N. Proposing an integrated model for evaluation of green and resilient suppliers by path analysis SWARA and TOPSIS. J. Appl. Res. Ind. Eng. 2021, 8, 129-149. [CrossRef] 
37. Xiong, L.; Zhong, S.; Liu, S.; Zhang, X.; Li, Y. An Approach for Resilient-Green Supplier Selection Based on WASPAS, BWM, and TOPSIS under Intuitionistic Fuzzy Sets. Math. Probl. Eng. 2020, 2020, 1761893. [CrossRef]

38. Dong, Y.; Deng, X.; Hu, X.; Chen, W. A novel stochastic group decision-making framework with dual hesitant fuzzy soft set for resilient supplier selection. J. Intell. Fuzzy Syst. 2021, 41, 1049-1067. [CrossRef]

39. Pamucar, D.; Yazdani, M.; Obradovic, R.; Kumar, A.; Torres-Jiménez, M. A novel fuzzy hybrid neutrosophic decision-making approach for the resilient supplier selection problem. Int. J. Intell. Syst. 2020, 35, 1934-1986. [CrossRef]

40. Zhang, J.; Yang, D.; Li, Q.; Lev, B.; Ma, Y. Research on Sustainable Supplier Selection Based on the Rough DEMATEL and FVIKOR Methods. Sustainability 2020, 13, 88. [CrossRef]

41. Cui, L.; Wu, H.; Dai, J. Modelling flexible decisions about sustainable supplier selection in multitier sustainable supply chain management. Int. J. Prod. Res. 2021, 1-22. [CrossRef]

42. Schramm, V.B.; Cabral, L.P.B.; Schramm, F. Approaches for supporting sustainable supplier selection-A literature review J. Clean. Prod. 2020, 273, 123089. [CrossRef]

43. Wei, C.; Wu, J.; Guo, Y.; Wei, G. Green supplier selection based on codas method in probabilistic uncertain linguistic environment Technol. Econ. Dev. Econ. 2021, 27, 530-549. [CrossRef]

44. Bakhtiari Tavana, A.; Rabieh, M.; Esmaeili, M. A Stochastic Programming Model of Sustainable-Resilient Supplier Selection and Order Allocation under Disruption Risks-The Case of Iran-Khodro Supply Chain. J. Prod. Oper. Manag. 2020, 11, 111-132.

45. Mohammed, A.; Harris, I.; Soroka, A.; Mohamed, N.; Ramjaun, T. Evaluating green and resilient supplier performance: AHPfuzzy topsis decision-making approach. In Proceedings of the 7th International Conference on Operations Research and Enterprise Systems, Funchal, Portugal, 24-26 January 2018. [CrossRef]

46. Tundys, B. Sustainable supplier selection criteria in the context of developing of green supply chain. In Proceedings of the 5th IEEE International Conference on Advanced Logistics \& Transport (ICALT), Krakow, Poland, 1-3 June 2016; pp. 147-153.

47. Jiang, P.; Hu, Y.-C.; Yen, G.-F.; Tsao, S.-J. Green supplier selection for sustainable development of the automotive industry using grey decision-making. Sustain. Dev. 2018, 26, 890-903. [CrossRef]

48. Wang, T.-K.; Zhang, Q.; Chong, H.-Y.; Wang, X. Integrated Supplier Selection Framework in a Resilient Construction Supply Chain: An Approach via Analytic Hierarchy Process (AHP) and Grey Relational Analysis (GRA). Sustainability 2017, 9, 289. [CrossRef]

49. Alimohammadlou, M.; Bonyani, A. An integrated fuzzy model for resilient supplier selection. Int. J. Supply Chain Manag. 2018, 7,35 .

50. Pramanik, D.; Haldar, A.; Mondal, S.C.; Naskar, S.K.; Ray, A. Resilient supplier selection using AHP-TOPSIS-QFD under a fuzzy environment. Int. J. Manag. Sci. Eng. Manag. 2016, 12, 45-54. [CrossRef]

51. Gan, J.; Zhong, S.; Liu, S.; Yang, D. Resilient Supplier Selection Based on Fuzzy BWM and GMo-RTOPSIS under Supply Chain Environment. Discret. Dyn. Nat. Soc. 2019, 2019, 2456260. [CrossRef]

52. Wu, Q.; Zhou, L.; Chen, Y.; Chen, H. An integrated approach to green supplier selection based on the interval type-2 fuzzy best-worst and extended VIKOR methods. Inf. Sci. 2019, 502, 394-417. [CrossRef]

53. Celik, E.; Gul, M. Hazard identification, risk assessment and control for dam construction safety using an integrated BWM and MARCOS approach under interval type-2 fuzzy sets environment. Autom. Constr. 2021, 127, 103699. [CrossRef]

54. Tang, J.; Liu, X.; Wang, W. A hybrid risk prioritization method based on generalized TODIM and BWM for Fine-Kinney under interval type-2 fuzzy environment. Hum. Ecol. Risk Assess.: Int. J. 2020, 27, 954-979. [CrossRef]

55. Waleekhajornlert, N.; Sureeyatanapas, P. Resilient Supplier Selection under Uncertainty Using the Extended TOPSIS Method: The Case of Electronic Components Procurement. Int. Sci. J. Eng. Technol. 2020, 4, 44-49.

56. Rezaei, J. Best-worst multi-criteria decision-making method: Some properties and a linear model. Omega 2016, 64, 126-130. [CrossRef]

57. Mousakhani, S.; Nazari-Shirkouhi, S.; Bozorgi-Amiri, A. A novel interval type-2 fuzzy evaluation model based group decision analysis for green supplier selection problems: A case study of battery industry. J. Clean. Prod. 2017, 168, 205-218. [CrossRef]

58. Guo, S.; Zhao, H. Fuzzy best-worst multi-criteria decision-making method and its applications. Knowl. Based Syst. 2017, 121, 23-31. [CrossRef]

59. Hasan, M.; Jiang, D.; Ullah, A.S.; Alam, N.E. Resilient supplier selection in logistics 4.0 with heterogeneous information. Expert Syst. Appl. 2019, 139, 112799. [CrossRef] 